\title{
„Czegoś podobnego dotychczas w Warszawie nie było". Wystawa Towarzystwa Polska Sztuka Stosowana w Zachęcie w 1908 r.
}

Z ałożone w roku 1901 w Krakowie Towarzystwo Polska Sztuka Stosowana (TPSS) stawiało przed sobą następujące cele: ,szerzenie zamiłowania do polskiej sztuki stosowanej, ułatwianie jej rozwoju i wprowadzanie jej do przemysłu"1. Założenia te miały być realizowane poprzez publikacje, wykłady, wystawy, konkursy, zakładanie warsztatów, wspieranie produkcji i sprzedaż polskiej sztuki stosowanej, zakup dzieł i rozlosowywanie ich między członków Towarzystwa, a także kolekcjonowanie materiałów ludowych z ziem ,gdzie tylko brzmi mowa polska"2. Do roku 1908 udało się zrealizować dużą część tych postulatów. Zorganizowano kilka większych wystaw ${ }^{3}$, a także sporo mniejszych ekspozycji pokonkursowych, nawiązano stałą współpracę z warsztatem kilimkarskim Antoniny Sikorskiej w Czernichowie pod Krakowem oraz przeprowadzono szereg konkursów z dziedziny projektowania mebli, wnętrz, druków i architektury, które ułatwiły kontakty pomiędzy artystami-projektantami a instytucjami publicznymi, firmami komercyjnymi i prywatnymi zleceniodawcami. TPSS otrzymało też kilka większych prestiżowych zleceń - zaprojektowanie wnętrz restauracji w krakowskim Starym Teatrze oraz w mieszkaniu prezydenta Krakowa Juliusza Leo; pojawiło się również wiele zamówień prywatnych na meble i kilimy.

Podsumowaniem kilkuletniej działalności TPSS miała być wystawa zorganizowana w warszawskim Towarzystwie Zachęty Sztuk Pięknych (TZSP), którą zwiedzać można było od 1 lutego do 12 marca 1908 r. Organizacją ekspozycji zajęli się Józef Czajkowski, Jerzy Warchałowski, Karol Tichy i Edward Trojanowski. O jej założeniach tak pisano w Sprawozdaniu Towarzystwa za rok 1908: „Celem wystawy było wykazanie, że sztuka stosowana polska jest, że jest już szereg artystów, który kilkoletnią świadomą celu pracą dowiedli, że w zakresie urządzania wnętrz mieszkalnych, a więc przede wszystkim w meblarstwie i dekoracji ścian, może i u nas własnymi środkami, na gruncie rodzinnym,

\footnotetext{
* Artykuł powstał w ramach projektu badawczego Ojcowie polskiego designu. Towarzystwo Polska Sztuka Stosowana. Architektura wnętrz i meblarstwo finansowanego przez Narodowe Centrum Nauki (2015/17/D/HS2/01215).

${ }^{1}$ Statut Towarzystwa „Polska Sztuka Stosowana”, Kraków 1901, s. 1.

2 Sprawozdanie Towarzystwa „Polska Sztuka Stosowana” w Krakowie 1901-02, Kraków 1903, s. 4.

${ }^{3}$ M.in. wystawy w Krakowie i Warszawie (1902), wystawa w Krakowie wraz z Towarzystwem Artystów Polskich „Sztuka” (1903), wystawa drukarska w Krakowie (1904).
} 

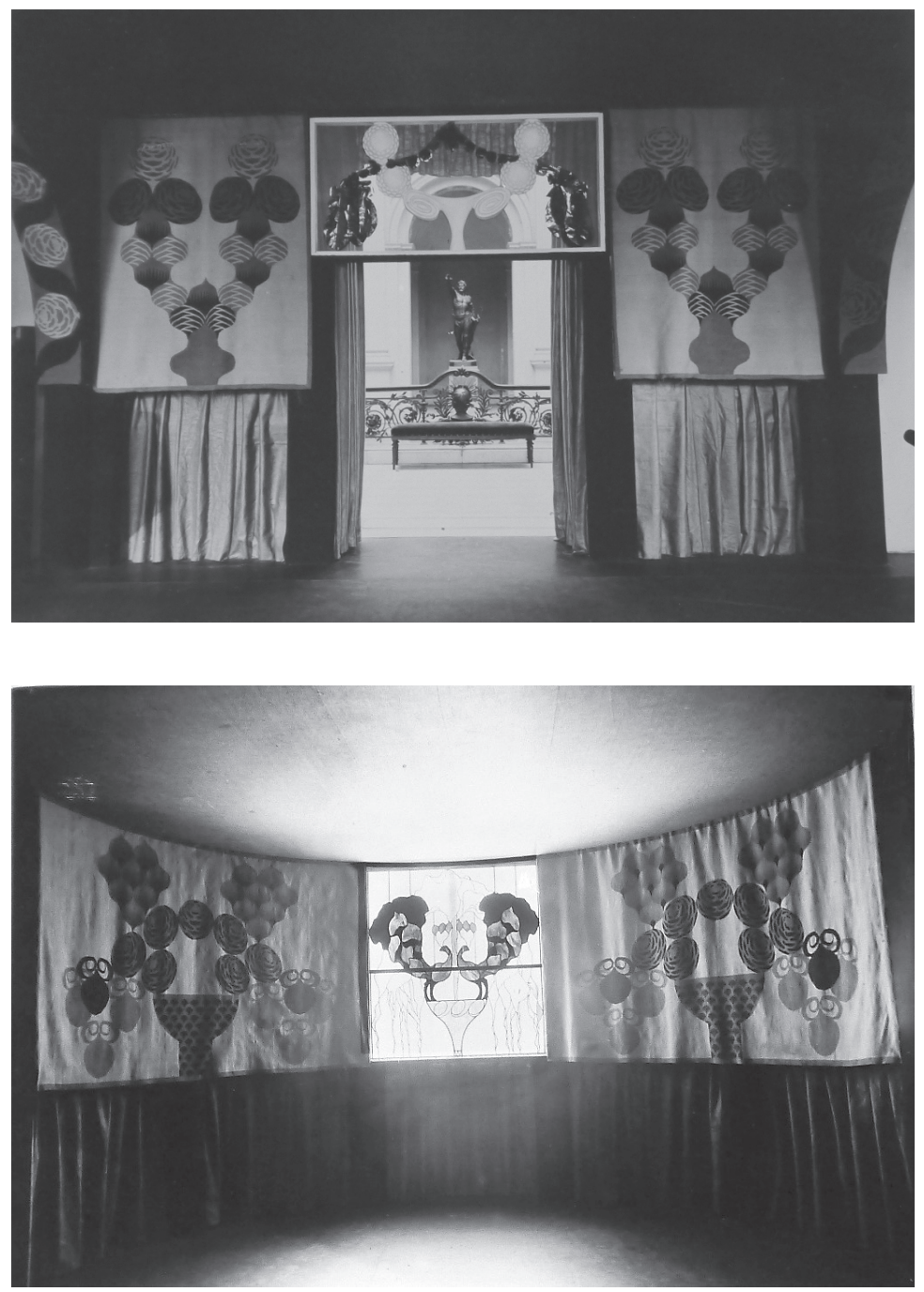

1-2. Karol Tichy, sień na wystawie TPSS w Zachęcie, kilimy z warsztatu Antoniny Sikorskiej, 1908. Fot. ze zbiorów Gab. Ryc. ASP w Krakowie

zająć stanowisko samodzielne i artystyczne w całym słowa tego znaczeniu"4. Artyści mogli nadsyłać „oryginalne prace polskie” do TPSS (do 1 października 1907) i TZSP (do 1 stycznia 1908). Wystawa dawała także możliwość sprzedaży prezentowanych przedmiotów lub zamówienia kolejnych egzemplarzy ${ }^{5}$. O postępach w jej organizacji, nadsyłaniu z Krakowa kolejnych prac i wykonywaniu w Warszawie sprzętów na ekspozycję informował na bieżąco „Kurier Warszawski”6.

Wystawa TPSS zajęła dziesięć sal, z czego siedem było aranżacjami wnętrz mieszkalnych. Pierwszym pomieszczeniem była sień projektu Tichego, skąd, idąc w prawo, przemierzało się kolejno: zaprojektowany przez Trojanowskiego gabinet Władysława Reymonta, jadalnię Żeleńskich autorstwa Stanisława Wyspiańskiego oraz jadalnię Dziewulskich projektu Ludwika Wojtyczki, by dojść do sypialni Marii Papieskiej będącej dziełem Trojanow-

\footnotetext{
${ }^{4}$ VII. Sprawozdanie Towarzystwa „Polska Sztuka Stosowana” w Krakowie r. 1908, Kraków 1909, s. 5.

5 „Wystawa”, Architekt, 1907, nr 8, szp. 23, 24.

${ }^{6}$ „Ze sztuki”, Kurier Warszawski, 1908, nr 21 (21 I), s. 2; nr 24 (24 I), s. 3; nr 26 (26 I), s. 5; nr 30 (30 I), s. 5; nr 31 (31 I), s. 4; nr 32 (1 II), s. 4.
} 


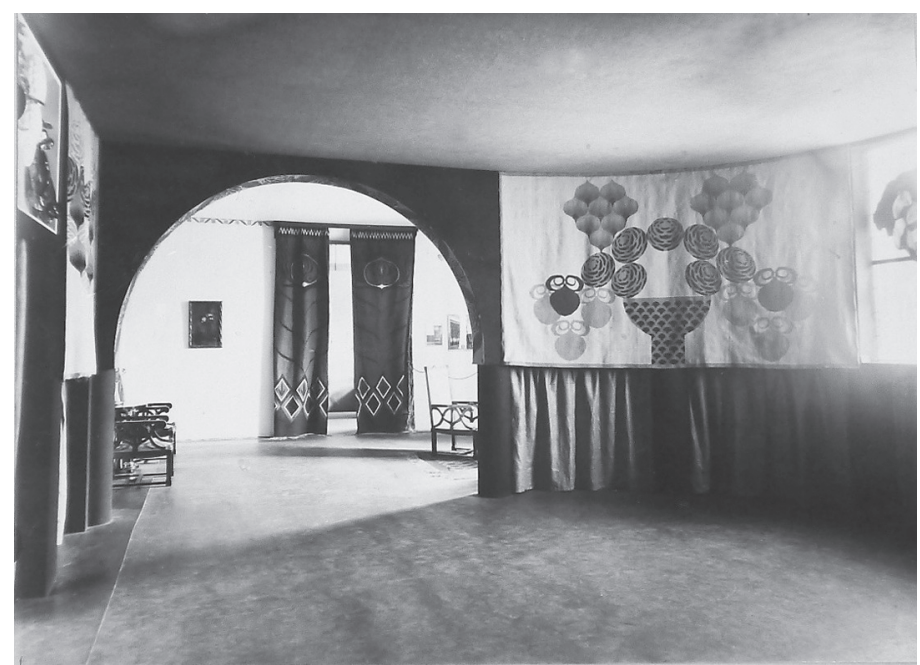

3. Karol Tichy, sień na wystawie TPSS w Zachęcie, w tle przedpokój projektu Józefa Czajkowskiego, 1908. Fot. ze zbiorów Gab. Ryc. ASP w Krakowie

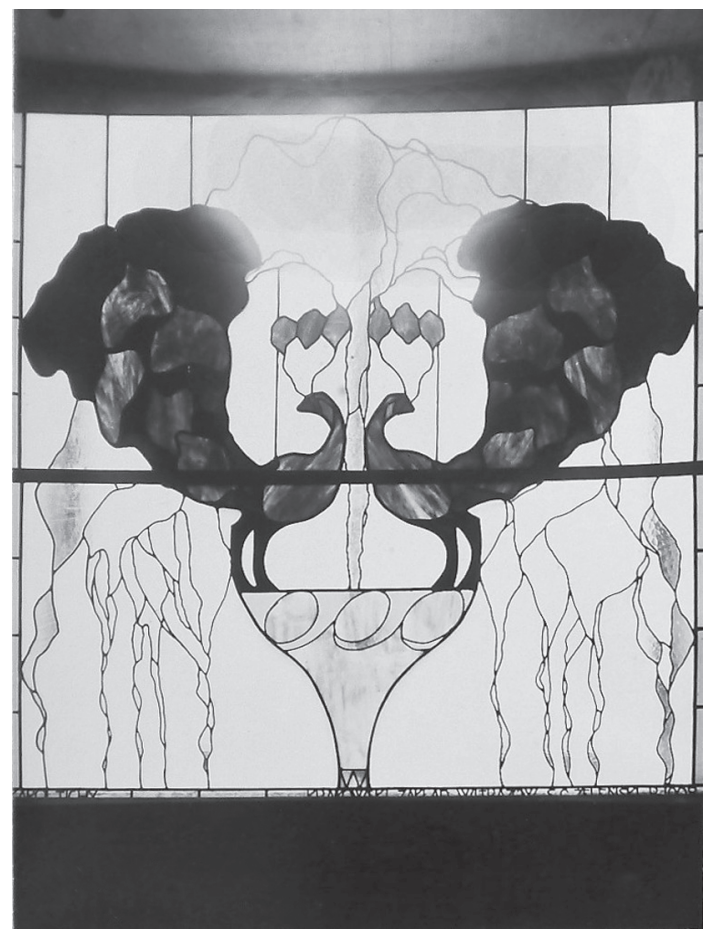

4. Karol Tichy, witraż, Krakowski Zakład Witrażów S. G. Żeleński, 1908.

Fot. ze zbiorów Gab. Ryc. ASP w Krakowie

skiego. Kierując się z sieni w lewą stronę, można było zobaczyć przedpokój projektu Czajkowskiego, a następnie meble Wyspiańskiego do salonu Żeleńskich i jadalnię Reymontów autorstwa Czajkowskiego. Osobną salę przeznaczono na prace Józefa Mehoffera oraz druki i projekty dekoracyjne. Eksponatami wypełniono także dwa korytarze ${ }^{7}$. Aranżacja części

\footnotetext{
${ }^{7}$ Wystawa krakowskiego Towarzystwa „Polska Sztuka Stosowana” w gmachu Towarzystwa Zachęty Sztuk Pięknych w Warszawie w lutym 1908 r., Kraków 1908.
} 
wystawy na wzór ciągu pomieszczeń mieszkalnych z obniżonymi sufitami wzbudziła w widzach zdumienie i wywołała pozytywny odzew ${ }^{8}$. Eligiusz Niewiadomski notował: „Czegoś podobnego dotychczas w Warszawie nie było" pozycja, opisywano zaś następująco: „Wystawa ma wygląd miłego, wesołego, dobrze utrzymanego mieszkania. Na oknach, za muślinem jasnych firanek, doniczki z kwitnącymi roślinami, w pokojach pełno kwiatów ciętych. Na ścianach obrazki, rysunki. Nareszcie mamy nie chaotyczne zbiorowisko sprzętów, drobiazgów i różnych okazów sztuki stosowanej, lecz całkowicie urządzone mieszkanie, dające miarę reformatorskich dążeń nowych ludzi, artystów"10.

Zwiedzający wchodzili najpierw do sieni projektu Karola Tichego, dekorowanej kilimami wykonanymi w warsztatach Antoniny Sikorskiej i witrażem pochodzącym z zakładu Stanisława Gabriela Żeleńskiego ${ }^{11}$. Wnętrze zostało zaprojektowane symetrycznie: na wprost wejścia umieszczono witraż, a po jego bokach dwa poziome kilimy. Nad wejściem znajdowała się dekoracyjna rzeźba z gipsu, zaś po obu jej stronach dwa kilimy pionowe. Szczęśliwie przykłady obydwu zaprojektowanych przez Tichego rodzajów kilimów zachowały się w zbiorach Muzeum Narodowego w Krakowie. Oba warianty to kompozycje symetryczne. Na osi projektant umieścił stylizowany wazon-czarę, z której wyłaniają się pąki kwiatów zbliżonych do chryzantem, róż lub buldeneży, w części poddane bardzo silnemu formalnemu uproszczeniu. Ich kolorystyka jest stonowana - na szarobiałym tle umieszczono motywy w tonacji zgaszonych żółcieni, brązów, czerwieni i szarości. Motyw wazy z kwiatami Tichy konsekwentnie powtórzył w dekoracji nad drzwiami, w której jeszcze silniej zgeometryzował kształt czary i pąków oraz dodał dwie symetryczne, złocone gałązi z liśćmi. Rzeźbiarska dekoracja była niejako odbiciem witraża przedstawiającego fontannę-wazę, na brzegu której przysiadły dwa antytetycznie ujęte pawie. Całość kompozycji dopełniała polichromia podłuczy, również zdobionych motywami kwiatowych pąków oraz listków ${ }^{12}$. Dzięki informacjom prasowym możemy odtworzyć kolorystykę wnętrza sieni w Zachęcie: „Wchodzimy na wystawę przez niskie wejście, ujęte w obficie sfałdowaną kotarę z naturalnego płótna; nad nim ażurowa dekoracja rzeźbiona w gipsie. Duża sień w kształcie podłużnego półkola. W głębi - witraż: wyobraża dwa fantastyczne ptaki, mieniące się gamą czerwonych tonów na tle stylizowanych białych wód fontanny. Na niskich ciemno-czerwonych filarach, obiegających sień dokoła, spoczywają ściany, zawieszone wielkimi tkaninami kilimowymi o subtelnym rysunku w jasnych kolorach. W sieni panuje półmrok, rozjaśniony silną grą kolorowych szkieł witrażu"13.

W motywach dekoracyjnych zastosowanych w sieni odnaleźć możemy inspiracje sztuką ludową. Kwiaty wyrastające z waz mogą kojarzyć się z dekoracjami skrzyń ludowych, natomiast pawie w pewnym stopniu wiążą się z wycinankami. Nie ma tu jednak miejsca na żadną dosłowność czy też powielanie motywów ludowych. Artysta stylizował dekora-

\footnotetext{
${ }^{8}$ E. Żm. [Eugenia ŻMIJEWSKA], ,Sztuka Polska Stosowana”, Słowo, 1908, nr 36 (6 II), s. 2.

${ }^{9}$ Eligiusz NIEWIADOMSKI, „O polskiej sztuce stosowanej i jej przyjęciu w Warszawie”, Witeź, 1908, z. 7, s. 365.

${ }^{10}$ Teki Jerzego Warchałowskiego, Biblioteka Akademii Sztuki Pięknych w Krakowie, sygn. 20028, (dalej: Teki...), karta 12, 13: „Wystawa «polskiej sztuki stosowanej»”, [niezidentyfikowane czasopismo], 1908 (5 III).

${ }^{11}$ Wystawa krakowskiego Towarzystwa „Polska Sztuka Stosowana” w gmachu Towarzystwa Zachęty Sztuk Pięknych w Warszawie w lutym 1908 r., op. cit., s. 6.

${ }^{12}$ Motywy wykorzystane w witrażu, uzupełnione o zgeometryzowane i poddane jeszcze większemu uproszczeniu rozety, Tichy wykorzysta kilka lat później, dekorując fasadę i sień w domu własnym w Krakowie przy placu Na Groblach. Por. Jerzy KORZENIOWSKI, „Karol Tichy (zarys monograficzny)”, Zeszyty Naukowe Akademii Sztuk Pięknych w Warszawie, 1988, z. 3, s. 29-34.

13 Teki..., sygn. 20028, karta 12, 13: „Wystawa «polskiej sztuki stosowanej»”, op. cit.
} 
cje, dochodząc do form mocno zgeometryzowanych, czym zapowiadał, podobnie jak w swoim projekcie mebli do sypialni, stylistykę art déco. W sposobie upraszczania pąków kwiatów bliski był projektom Charlesa Rennie Mackintosha. Kompozycje kilimów Tichego charakteryzujących się wąską gamą barwną, uproszczeniem i geometryzacją motywów floralnych możemy zestawić także z projektami artystów skandynawskich z początku XX w. Tego typu dekoracje pojawiły się w domu Hansa Christiansena w Darmstadcie. Ich motywem przewodnim był kwiat róży, który w formie mocno uproszczonej, czasami też w postaci pąków wyłaniających się z wazonów, pojawiał się między innymi na kotarach zasłaniających okna, drzwi i oddzielających hol od salonu ${ }^{14}$. W zbliżony sposób kwiaty stylizował też Eliel Saarinen. Jego projekt dywanu Róża z 1904 r. był wariacją na temat krzewu różanego, który zamienił się w abstrakcyjny, eliptyczny, dekoracyjny $z$ nak $^{15}$. Wobec upodobania Tichego do podobnych zgeometryzowanych form wyjątkowym może wydawać się zaprojektowany przez niego witraż do sieni, w którym dostrzec możemy z kolei dominację linii miękkich i płynnych.

Bardzo spójny, oddziaływujący prostymi kształtami i zawężoną kolorystyką projekt wnętrza sieni autorstwa Tichego wywoływał różne reakcje krytyków. Zdecydowanie negatywnie wypowiadał się o nim Tadeusz Jaroszyński, który przyznał, że: „racji bytu [sieni] po prostu wytłumaczyć nie jestem zdolny". Szczególnie nieudana była według niego dekoracja nad drzwiami wejściowymi, o której pisał: „Nad wejściem, na cienkiej listewce drewnianej wznosi się ogromna, ciężka bryła gipsu. Jest to podwójna ślimacznica, oparta uciętą kolumną na listwie, a dźwigająca na zwojach po dwie duże bezkształtne kule. Wszystko to związane, niby girlanda, sutymi wiechciami złotych liści”. Kompozycja ta, zdaniem Jaroszyńskiego, zbyt „ciężka [...], uciskająca na ciężką deskę, tuż nad głową osób wchodzących na wystawę sprawia wrażenie niepokojące i tym samym niezmiernie dalekie od uczucia estetycznego [...] Poza tym kule te, tak niedołężnie wymodelowane, nie tłumaczą swojego znaczenia zdobniczego". Z aprobatą spotkały się jedynie stylizowane pąki róż na kilimach „,rozrzucone asymetrycznie po szarej płaszczyźnie tkaniny”, które, pomimo swej prostoty, wywoływać miały „efekt wdzięczny i malowniczy”. Jaroszyński doszedł do wniosku, że artysta nie poradził sobie jednak z ornamentem w formie przestrzennej ${ }^{16}$. Henryk Stiefelman natomiast krytycznie pisał o witrażu, w którym ,pojedyncze części uraggają logice i technice witrażowej”" ${ }^{17}$. W opinii Adolfa Nowaczyńskiego z kolei sień Tichego sprawiała wrażenie „romańskiej powagi”, on sam zaś jawił się jako ,protektor czerwono-biało-złotości, żongler dwóch linii półkolistych, dyskretnego koloru"18. Rozwiązania kolorystyczne Tichego nie u wszystkich krytyków znalazły zrozumienie. Antoni Gawiński pisał: „Całość obliczona na ton czerwieni słabnącej stopniowo, aż do spopielałych, szarych harmonii [...] w rozumieniu kolorystycznym zatrąca o niemiły paradoks: róże, odbarwione ze swych uroków, wystylizowane jednakowo, skojarzone z równie odbarwionymi pawimi piórami, działają dosyć nużąco [...] Pomysł skojarzeń bieli, czerwieni i złota, otaczający wejście główne, wytwarza nastrój pewnej wspaniałości - przepychu, który nie znajduje konsekwentnie wysnutych przedłużeń w szaro-żółtawych kilimach"19.

\footnotetext{
${ }^{14}$ Deutsche Kunst und Dekoration, 1901-1902, t. 9, s. 60, 65, 66, 67.

${ }^{15}$ Charlotte FIELL, Peter FIELL, Design scandinave, Köln 2013, s. 570.

${ }^{16}$ Tadeusz JAROSZYŃSKI, „Sztuka stosowana”, Kurier Warszawski, 1908, nr 47 (16 II), s. 3-4.

${ }^{17}$ Henryk STIFELMAN, „,Wystawa Towarzystwa Polskiej Sztuki Stosowanej”, Przeglad Techniczny, 1908, nr 8, s. 105.

${ }^{18}$ Adolf NOWACZYŃSKI, „Sztuka stosowana w Warszawie”, Prawda, 1908, nr 6, s. 69-70.

${ }^{19}$ Antoni GAWIŃSKI, „Polska Sztuka Stosowana”, Nowa Gazeta, 1908, nr 75 (14 II), s. 2, 3.
} 


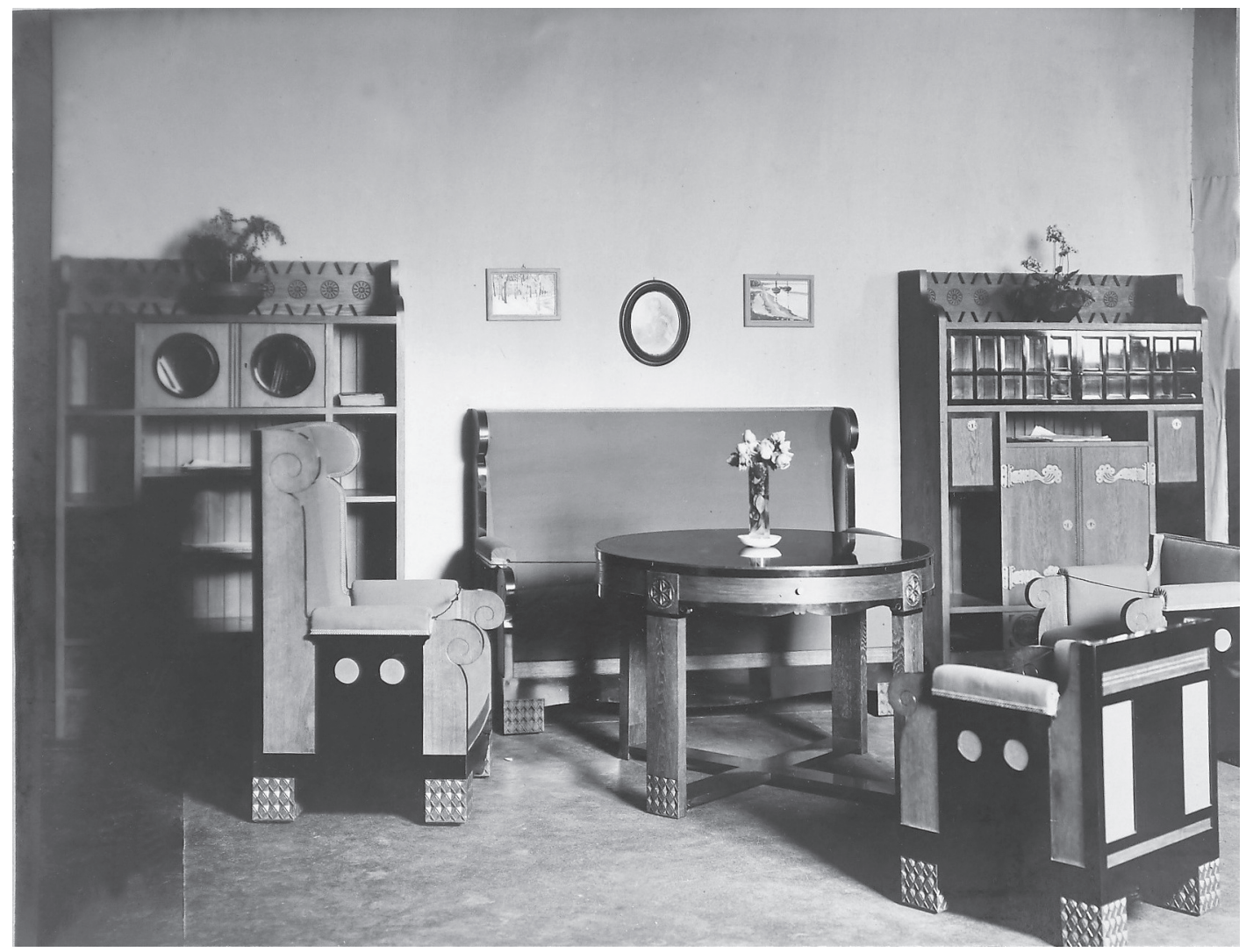

5. Edward Trojanowski, meble do gabinetu Wtadystawa Reymonta, wystawa TPSS w Zachęcie, 1908. Fot. ze zbiorów Gab. Ryc. ASP w Krakowie

Wystrój zaprojektowanego przez Trojanowskiego gabinetu Reymonta składał się z kanapy, dwóch szafek na książki, dwóch typów foteli oraz stołu. Sprzęty były wykonane z drewna dębowego i mahoniu, a obicia miały kolor ciemnoniebieski. Tło dla kompletu tworzyły prawie białe ściany, kilimy z pracowni Sikorskiej i niewielkie obrazy ${ }^{20}$. W meblach widoczna była jeszcze fascynacja Trojanowskiego ornamentyką ludową, która często dochodziła do głosu w jego wcześniejszych projektach. Do ludowej snycerki nawiązywały zakończenia szczytów mebli przybierające formy naprzemiennie umieszczonych trapezoidalnych zębów. Motywem bardzo często stosowanym przez projektanta były także, inspirowane być może zdobieniami skrzyń ludowych, przestylizowane i symetryczne gałązki, zastosowane tu w projekcie okuć na szafce. W komplecie mebli dla Reymonta możemy dostrzec też subtelne nawiązania do meblarstwa okresu biedermeieru. Trojanowski, podobnie jak czyniono to w 1. połowie XIX w., posłużył się zestawieniami dwóch kolorów drewna - jasnego korpusu i ciemnych detali. Użył także elementów wywodzących się z biedermeieru, czego przykładem były ciemne, kwadratowe szprosy przeszkleń oraz woluty. Najbardziej interesującymi meblami w tym komplecie są fotele i kanapa. Oba typy foteli - z wysokim i niskim oparciem - były zwartymi, kubicznymi formami, stworzonymi z kwadratów, prostokątów i kół. Konstrukcja siedzisk została podporządkowana kątom prostym, a ornamentyka nie miała już nic wspólnego z ludowymi gwiazdkami, czy ząbkami. Kubiczność mebli przełamały przeskalowane woluty tworzące zakończenia po-

20 Teki..., sygn. 20029, karta 197: Lucyna KOTARBIŃSKA, „Wystawa Sztuki Stosowanej w Krakowie”, Kuryer Literacki, 1908 (10 II); Teki..., sygn. 20028, karta 12, 13: „Wystawa «polskiej sztuki stosowanej»”, op. cit.; E. Żm. [Eugenia ŻMIJEWSKA], op. cit. 


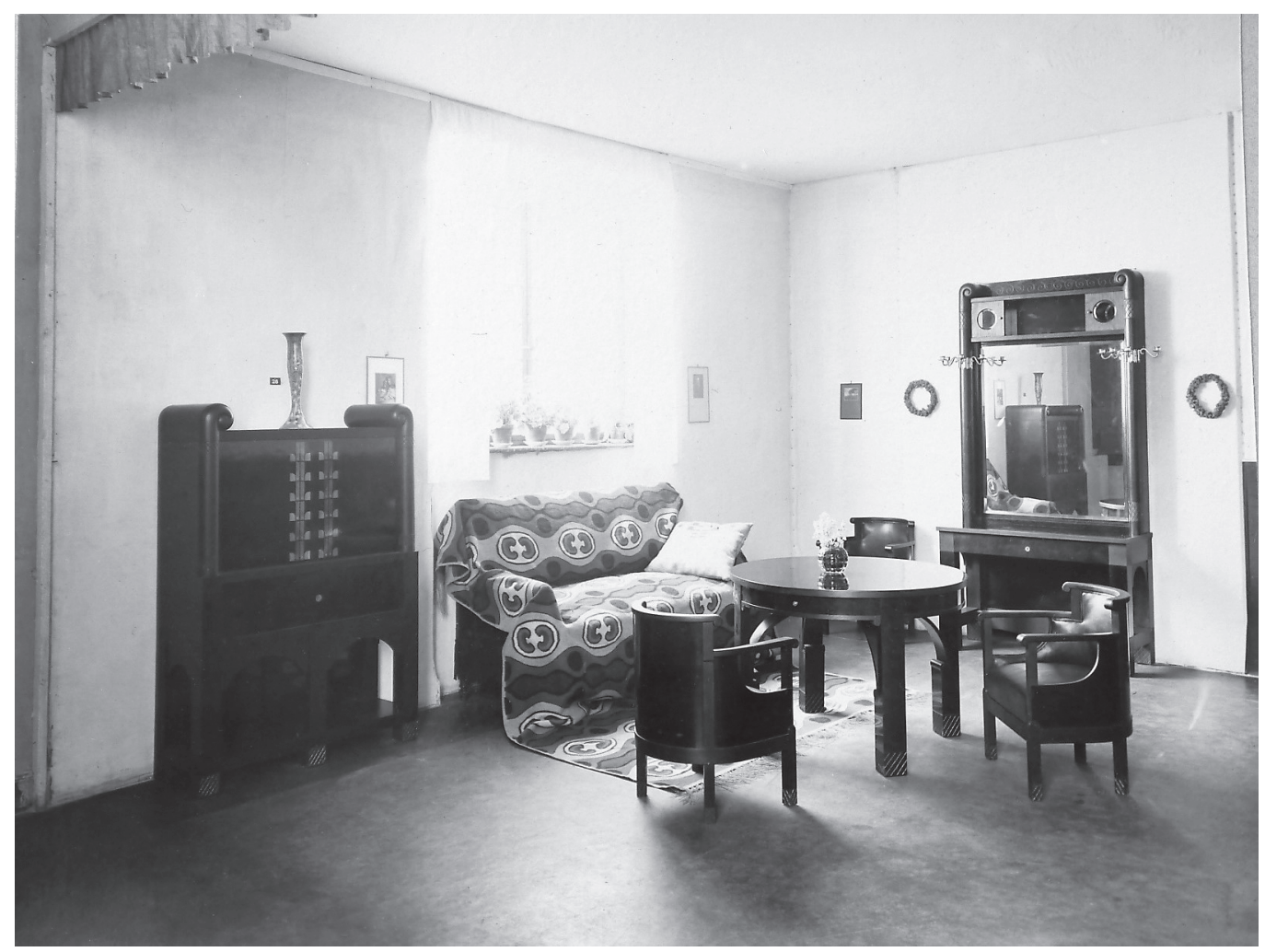

6-7. Edward Trojanowski, meble do sypialni Marii Papieskiej, wystawa TPSS w Zachęcie, 1908.

Fot. ze zbiorów Gab.

Ryc. ASP w Krakowie

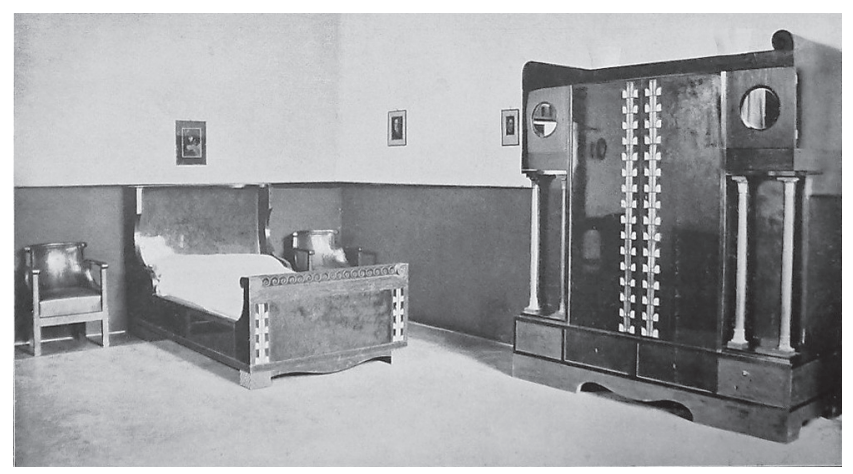

ręczy i uszaki. Trojanowski eksperymentował z możliwościami operowania formami geometrycznymi. Wykorzystał także potencjał zestawień dwóch odcieni drewna oraz efekt, jaki dawało skontrastowanie ich z kolorem tkaniny obiciowej ${ }^{21}$. Projekt kanapy i foteli do gabinetu Reymonta był jednym z najbardziej innowacyjnych w twórczości meblarskiej Trojanowskiego.

Dla Marii Papieskiej Trojanowski zaprojektował rozbudowany komplet mebli do sypialni, z którego tylko część pokazano na wystawie w Zachęcie. W jego skład, oprócz łóżka, szafki nocnej, szafy, parawanu, toaletki z lustrem i krzesła, wchodził także zestaw sprzętów tworzących salonik-buduar: stół, kanapa, foteliki, fotel, biurko, stolik oraz półki narożne ${ }^{22}$. Meble wykonano $\mathrm{z}$ drewna jaworowego $\mathrm{z}$ elementami dębowymi i nadano im kolorystykę żółto-brunatną oraz ciemnoszarą ${ }^{23}$. Dopełniały je kilimy z Czernichowa

\footnotetext{
${ }^{21}$ Teki..., sygn. 20028, karta 12, 13: „Wystawa «polskiej sztuki stosowanej»”, op. cit.

${ }^{22}$ Informacja pochodzi z księgi inwentarzowej Muzeum Narodowego w Warszawie, gdzie meble przechowywane były do II wojny światowej (nr inw. 74361-74375).

${ }^{23}$ Teki..., sygn. 20028, karta 12, 13: „Wystawa «polskiej sztuki stosowanej»”, op. cit.
} 
i witraż ukazujący „bukiet żywych, barwnych kwiatów rzuconych na szyby - motyw swojski, a jednak nowy”, który wprowadzać miał „ton wesoły, mimo udręczonej twarzy Chrystusa, unoszącej się wśród tego kwiecia" "24. Meblom Papieskiej, podobnie jak Reymonta, projektant nadał zwarta, monumentalną formę urozmaiconą zgeometryzowanym ornamentem. Gdzieniegdzie widoczne są jeszcze wpływy rzemiosła ludowego (faliste fartuszki pod oskrzynieniem łóżka i szafy) i biedermeieru (kolumny w szafie, okragłe szybki w szafie i toaletce z lustrem). Niewiele możemy odnaleźć w tych meblach linii miękkich, płynnych czy wiotkich; dominują dostojne, ciężkie kształty przełamane gdzieniegdzie wyważonymi łukami. Za przykład mogą posłużyć fotele. Siedziska o masywnej formie tapicerowane od wewnątrz skórą zyskały tylko łukowato wygięte oparcia oraz takowe wsporniki poręczy. Wszystkie sprzęty łączyła ornamentyka, której motywem przewodnim była woluta zastosowana zarówno w formie przestrzennej, jak i płaszczyznowej. Wałki zakończone w górnej części wolutami ujmowały boki sekretarzyka, lustra i szafy. Mniejsze woluty pojawiły się również jako nosy poręczy, zakończenia górnych ramiaków foteli i przyczółka łóżka, a także pomiędzy blatem a nogą stołu oraz jako zakończenia jego łączyn. Trojanowski wykorzystał też ornament falistej wstęgi, który zastosował w górnej części przyczółka łóżka i nad lustrem. Woluty zostały skontrastowane z dekoracją w technice intarsji, którą wykonała Natalia Boberówna. Elementy intarsjowane umieszczone na klapie sekretarzyka, przyczółku łóżka i skrzydłach szafy miały prosty zgeometryzowany ornament, który z pewnego oddalenia przypominać mógł wstęgę z kokardkami. Tworzyła go podwójna linia ciągów prostokątów, do których w miejscach styku przylegały wykonane z innego drewna i zwrócone kątem prostym na zewnątrz ćwiartki koła. Ciężar mebli podkreślały szachownicowe nacięcia w dolnych partiach podpór (stół, fotele, sekretarzyk, łóżko), powtórzone też w górnej części wałków z boków lustra. Trojanowski zastosował, podobnie jak w wystroju gabinetu, efektowny kontrast dwóch gatunków drewna - jaworowego i dębowego, który w tym wypadku sprawił, że cały komplet utrzymany był w ,zestawieniu żółto-brunatnym i ciemno-szarym"25.

Wystawione w Zachęcie dwa komplety mebli projektu Trojanowskiego były często komentowane na łamach prasy. Meble do gabinetu Reymonta według Adolfa Nowaczyńskiego były monumentalne, dostojne, ,zdecydowane w liniach, ciche, łagodne w kolorze", ale stosowne dla intelektualisty władającego piórem ${ }^{26}$. Wnętrze to ocieplały kilimy niewidoczne na fotografiach. Zapewne też dlatego pisano o nim, że „,miło tu i przytulnie"27. Wnętrze sypialni Papieskiej Nowaczyński uważał za zaprojektowane „poważnie, mieszczańsko, omal po średniowiecznemu" ${ }^{28}$. Zainteresowanie wzbudzała ornamentyka mebli. Różnie wypowiadano się o dekoracyjnych wolutach. W „Słowie” pisano: „,...] każdy z tych mebli podtrzymuje po bokach kolumny czarne dębowe, zakończone ślimakiem - nadaje to pewną, bardzo wdzięczną miękkość" ${ }^{29}$. Ślimacznice te jednak nie wszystkim przypadły do gustu. Jaroszyński pisał: ,[...] boki tworzą grube, zaokraglone na tępo, jak ciasto, ściany z czarnego drzewa, zakończone grubymi zwojami. Otóż zwoje te wyskakują połową wałka nad powierzchnię szafy, i owo właśnie pół wałka jest przyklejone do ściany bocznej, z którą jakoby miało stanowić całość jednolitą. Daje to wrażenie

\footnotetext{
${ }^{24}$ E. Żm. [Eugenia ŻMIJEWSKA], op. cit.

${ }^{25}$ Teki..., sygn. 20028, karta 12, 13: „Wystawa «polskiej sztuki stosowanej»”, op. cit.

${ }^{26}$ Adolf NOWACZYŃSKI, „Sztuka stosowana w Warszawie”, Prawda, 1908, nr 6, s. 69-70.

${ }^{27}$ E. Żm. [Eugenia ŻMIJEWSKA], op. cit.

${ }^{28}$ NOWACZYŃSKI, op. cit.

${ }^{29}$ E. Żm. [Eugenia ŻMIJEWSKA], op. cit.
} 
fałszywe i nieprzyjemne, gdyż nie tylko znać dolną szparę przyklejoną, ale i słój drzewa rysuje się inaczej w wałku, a inaczej na ścianie". Jaroszyński, powołując się na idee Gottfrieda Sempera, twierdził, że dekoracja ta jest nieodpowiednia do mebli i niezgodna z materiałem, z którego ją wykonano ${ }^{30}$. Pozytywnie oceniano natomiast intarsje: ,[...] nader miłe [...] kombinacje barwne: drzewo jaworowe inkrustowane dębem matowym robiącym wrażenie skóry. Zbudowana w ten sposób szafa, szafeczka mniejsza oraz lustro, są nader piękne i poważne"31.

W opisach stylu zaprezentowanych w Zachęcie mebli Trojanowskiego podkreślano skłonność artysty do prostych linii i monumentalnych form, które pewnym recenzentom wydawały się nieodpowiednie dla ludzi początku XX w. Antoni Gawiński pisał: „,...] forma [mebli] zdradza sympatie do linii poważnych, surowych, dość ciężkich. I w gabinecie i w sypialni krzesła mają w sobie za wiele, na dzisiejsze czasy, jakiejś druidyczno-romańskiej ascezy, są to również więcej wymyślne siedziska, niż meble ludzi żywych, nerwowych i - wygodnych [...] Całość sypialni wydaje mi się zanadto surową i ascetyczną - niemal klasztorną. Stół ciężki, lecz piękny w formie, zamyka wrażenie ogólne" 32 . Meble Trojanowskiego zestawiano z zaprojektowanymi przez Wyspiańskiego i także pokazanymi w Zachęcie elementami wystroju jadalni i salonu Żeleńskich. Kazimierz Broniewski pisał o nich: ,[...] praktyczne przeznaczenie wykonanego sprzętu ustąpiło całkowicie miejsca i racji swojej jakiejś chęci wywołania nastroju mistycznego wagą i rozmiarami przedmiotów [...] są one ustawione raz na zawsze, umontowane niby jakieś machiny, których poruszać się nie powinno, że człowiek do nich, nie one do niego, winien się przystosować. Pierwsze wrażenie, jakie one czynią, to wrażenie masy, bryły, która w pamięci nie zostawia ani gry linii, ani gry motywów zdobniczych"33.

Jaroszyński, pisząc na łamach „Kuriera Warszawskiego” o meblach Trojanowskiego, uznał je za zbliżone do projektów zagranicznych. Komplet do gabinetu Reymonta zestawił z meblami niemieckimi i angielskimi, reprezentującymi typ sprzętów „ciężkich, sztywnych i mało ponętnych”, które można zobaczyć na przykład na łamach „Moderne Bauformen" 34 . Oburzony tym porównaniem Trojanowski zwrócił się za pośrednictwem redakcji z prośbą do Jaroszyńskiego o przesłanie numerów czasopisma, w których reprodukowane miały być projekty podobne do jego mebli. Jaroszyński odpowiedział wówczas, że nie posądza artysty o kopiowanie wzorów zachodnioeuropejskich, lecz widzi w jego pracach podobne cechy - pewną sztywność i płaszczyznowość 35 . Celne rozpoznanie Jaroszyńskiego nie odbiera słuszności także racjom Trojanowskiego, którego projekty w pewnych zestawieniach dowodzą tylko swojej innowacyjności.

Meble Trojanowskiego, o uproszczonej formie wykorzystującej jedynie zgeometryzowaną ornamentykę i walory dekoracyjne drewna, możemy łączyć z kręgiem artystów związanych z pierwszą fazą działalności Warsztatów Wiedeńskich. Szczególnie interesujące wydaje się zestawienie ich z pracami Josefa Hoffmanna, Kolomana Mosera czy Otto Prutschera. Wiedeńczycy, podobnie jak Trojanowski, nadawali meblom zwarta, zgeometryzowaną formę opartą na układach stworzonych z kwadratów i prostokątów. Fotele zaprojektowane dla Reymonta możemy zestawić z fotelami z kolekcji Österreichisches

\footnotetext{
${ }^{30}$ JAROSZYŃSKI, op. cit.

${ }^{31}$ GAWIŃSKI, op. cit.

${ }^{32}$ Ibid.

${ }^{33}$ Kazimierz BRONIEWSKI, „Wystawa T-wa «Polska Sztuka Stosowana»”, Goniec Wieczorny, 1908, nr 85 (20 II), s. $2,3$.

34 JAROSZYŃSKI, op. cit.

35 „Listy do redakcji”, Kurier Warszawski, 1908, nr 54 (23 II), s. 15.
} 


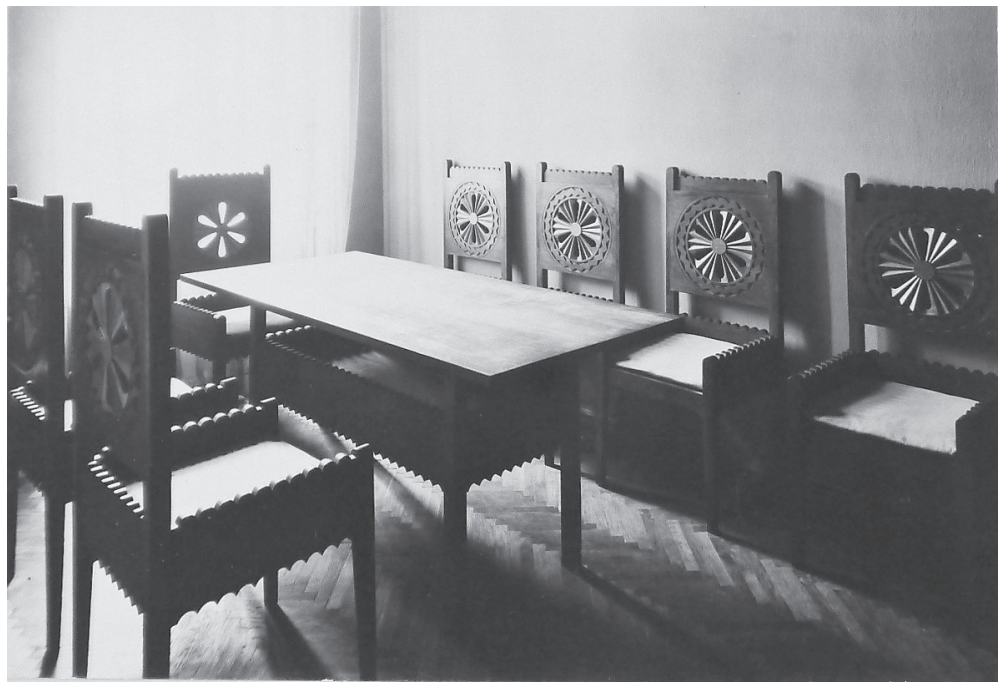

8. Stanistaw Wyspiański, meble do jadalni

Żeleńskich, wystawa TPSS w Zachęcie, 1908.

Fot. ze zbiorów Gab. Ryc. ASP w Krakowie

Museum für angewandte Kunst (MAK) - Hoffmanna z kompletu mebli dla Hermanna Wittgensteina (1905) i Mosera z kompletu mebli do gabinetu dla rodziny Waerndorfer (1903). Układy prostokątów i kół wykorzystane przez Trojanowskiego jako element zdobniczy (np. w meblach do gabinetu Reymonta) porównać można do abstrakcyjnych, geometrycznych układów kwadratów, które zastosował Hoffmann do dekoracji foteli i kanap w holu willi doktora Fiedricha Victora Spitzera (1900-1903) $)^{36}$, a także w meblach do salonu reprodukowanych w „Das Interieur” ${ }^{37}$. Również skłonność Trojanowskiego do podkreślania struktur mebli poprzez zastosowanie różnych gatunków drewna i tym samym nadawanie im dodatkowych walorów dekoracyjnych możemy łączyć z kręgiem artystów Warsztatów Wiedeńskich. Podobne rozwiązania zastosował chociażby Hoffmann w komplecie mebli do sypialni baronowej Mautner Markhof $(1902)^{38}$ czy Moser w stoliku z kompletu mebli dla Eislera von Terramare (1903) z kolekcji MAK.

Aby uczcić osiagnięcia Wyspiańskiego, honorowego członka TPSS, na wystawie zaprezentowano wybrane elementy z kompletów mebli zaprojektowanych dla Żeleńskich (żardinierę, dwa fotele, kanapę z salonu, stół i krzesła z jadalni), a także jego projekty dekoracyjne, rysunki i obrazy. Starano się odtworzyć też dobraną przez Wyspiańskiego kolorystykę, skutkiem czego meble do salonu wyeksponowano na tle ścian o odcieniu „barszczu zabielanego”. Na sprzęty do mieszkania Żeleńskich patrzono często przez pryzmat anegdotycznej Historii pewnych mebli, która utrwaliła obiegową opinię o niefunkcjonalności tego kompletu. Dopiero Anna Sieradzka zwróciła uwagę na ich awangardową formę i starała się udowodnić, że sprzęty Wyspiańskiego zapowiadały art déco. Jej zdaniem meble do salonu: „odznaczały się prostymi, zwartymi formami, których geometryczną surowość łagodziły geometryczne wygięcia i dyskretnie ząbkowane zakończenia dolnych partii sprzętów. W umeblowaniu tym uderza zarówno czystość linii określających niemal purystyczne formy, jak i jasna kolorystyka, wynikająca z naturalnych walorów tworzywa". Komplet projektu Wyspiańskiego Sieradzka zestawiła z białymi meblami Kolomana Mosera. Ciemne sprzęty do jadalni porównała natomiast z meblami w pałacu Stocletów projektu Josefa Hoffmanna. Pisała: „Oba dzieła łączy monumentalizm i prostota form, oszczędność dekoracji, całkowite podporządkowanie mebli rygorom geome-

\footnotetext{
${ }^{36}$ Art et Décoration, t. 16: 1904, s. 64, 67.

${ }^{37}$ Das Interieur, R. 4: 1904, s. 12.

${ }^{38}$ Innen-Dekoration, t. 16: 1905, s. 180, 182.
} 
9. Stanisław Wyspiański, czéść kompletu mebli do salonu Żeleńskich, wystawa TPSS w Zachęcie, 1908.

Fot. ze zbiorów Gab. Ryc.ASP w Krakowie

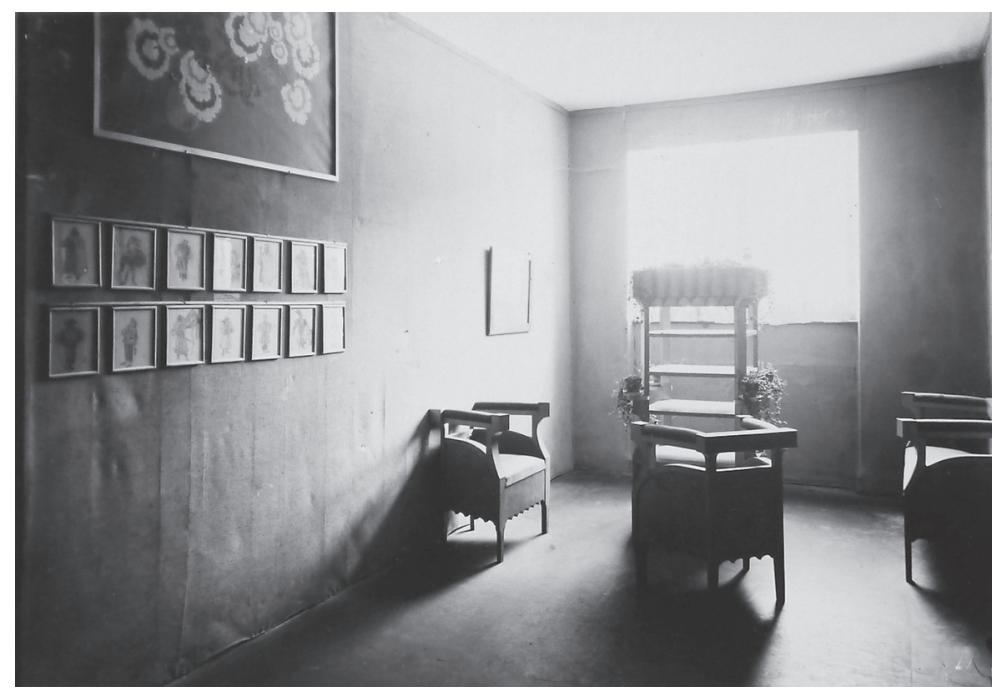

trii" ${ }^{39}$. Anna Kostrzyńska-Miłosz w meblach dla Żeleńskich dostrzegła inspiracje zdobnictwem góralskim, na co wskazywać miała nie tylko zwarta, zgeometryzowana forma, lecz także ornamentyka (np. stylizowane gwiazdy) ${ }^{40}$. Zestawienia tych mebli z projektami związanymi ze środowiskiem wiedeńskim bardzo dobrze wydobywają ich innowacyjność, a powiązanie ze sztuką ludową podkreśla także rodzime korzenie twórczości Wyspiańskiego. Te dwa tropy pozwalają zestawić meble dla Żeleńskich z projektami fińskimi z początku XX w. W meblarstwie Eliela Saarinena możemy odnaleźć te same cechy bryłowatość, monumentalność, pewną kanciastość, oddziaływanie dekoracyjnością samego materiału, a także subtelną ornamentykę wywodzącą się ze sztuki ludowej. Powiązania te są tutaj jedynie sygnalizowane i wymagają dalszej analizy.

Sprzęty Wyspiańskiego zwracały powszechną uwagę. Meble do jadalni odebrane zostały jako proste, surowe i chłodne $\mathrm{w}$ wyrazie ${ }^{41}$, niekiedy wręcz odstraszające. Lucyna Kotarbińska pisała o nich: „,...] robią na mnie osobiście wrażenie, że ja bym się tych mebli - bała. Sa jakieś dziwaczne, ostre, sztywne. Nie zapraszają. Odstraszaja" "22. Część mebli z salonu Żeleńskich uznano za „poważne”43, „,iężkie, masywne [...], które nazwać można anty-burżuazyjnymi ze względu na ich posępną surowość, kanciastość, okrutność przegubów i niesiedzistość" 44 . Zwracano uwagę, że są one bardzo niewygodne, niefunkcjonalne i nieodpowiadające potrzebom współczesnego człowieka ${ }^{45}$. Jako przykład podawano fotele, które: ,[...] zbudowane są z wielkich, grubych, o ostrych kantach bierwion. [...] tworzą całość ciężką i w najmniejszym nawet stopniu nie salonową. Poza tym owo kanciaste oparcie zwęża się ku tyłowi, tworząc kąt, w który nie wcisną się plecy nawet bardzo wątłej budowy człowieka"46. Tego typu meble, zdaniem Jaroszyńskiego, choć byłyby

\footnotetext{
${ }^{39}$ Anna SIERADZKA, ,Początki awangardy w meblarstwie polskim 1904-1914”, [w:] Studia z architektury nowoczesnej, t. 2, red. Joanna KUCHARZEWSKA, Jerzy MALINOWSKI, Toruń 2007, s. 134-136; ead., „Stanisław Wyspiański jako prekursor stylu Art Déco w polskim rzemiośle artystycznym", [w:] Rzemiosto artystyczne. Materiały Sesji Oddziału Warszawskiego Stowarzyszenia Historyków Sztuki, red. Ryszard BOBROW, Warszawa 1996, s. 137, 138.

${ }^{40}$ Anna KOSTRZYŃSKA-MIŁOSZ, Polskie meble 1918-1939. Forma - funkcja-technika, Warszawa 2005, s. $23,24$.

${ }^{41}$ E. Żm. [Eugenia ŻMIJEWSKA], op. cit.; NOWACZYŃSKI, op. cit.

${ }^{42}$ Teki..., sygn. 20029, karta 197: KOTARBIŃSKA, op. cit.

${ }^{43}$ E. Żm. [Eugenia ŻMIJEWSKA], op. cit.

${ }^{44}$ NOWACZYŃSKI, op. cit.

${ }^{45}$ GAWIŃSKI, op. cit.

${ }^{46}$ Tadeusz JAROSZYŃSKI, „Polska Sztuka Stosowana”, Biblioteka Warszawska, 1908, z. 1, s. 546-562.
} 


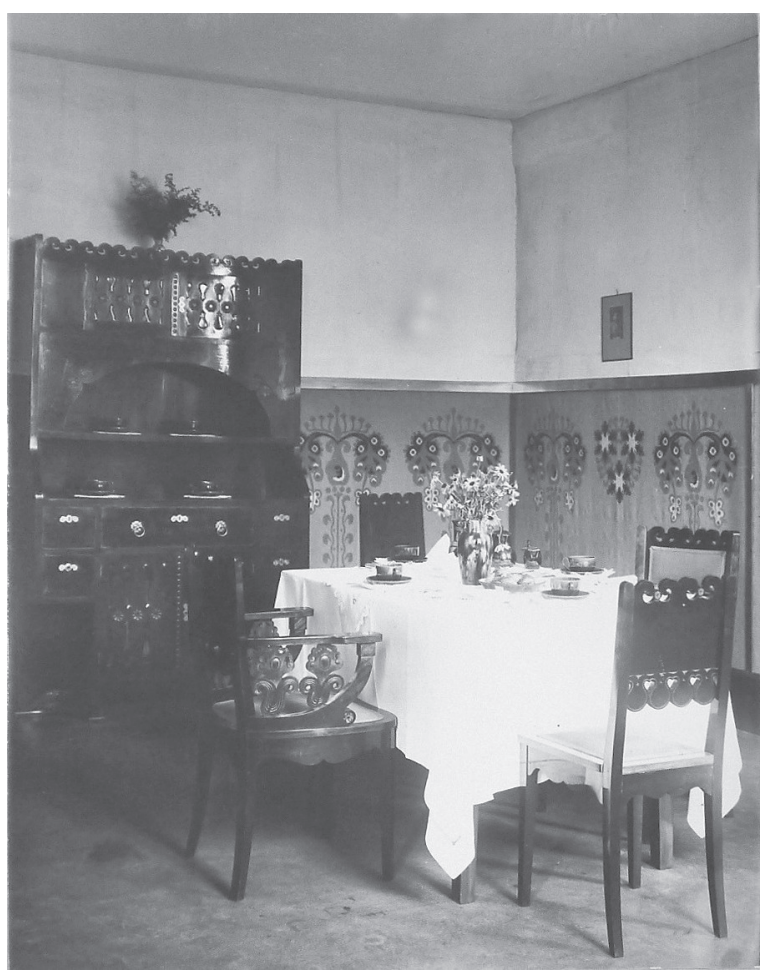

10. Ludwik Wojtyczko, meble do jadalni Dziewulskich, wystawa TPSS w Zachecie, 1908.

Fot. ze zbiorów Gab. Ryc. ASP w Krakowie

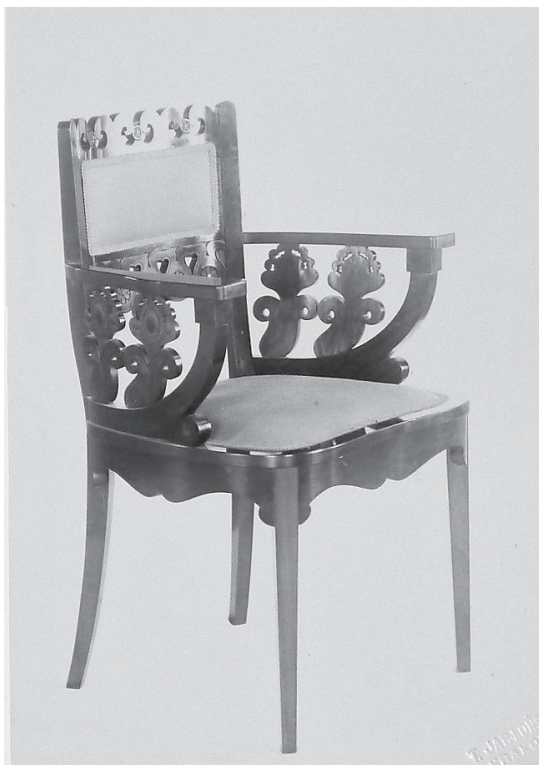

11. Ludwik Wojtyczko, fotel z kompletu mebli do jadalni Dziewulskich, wystawa TPSS w Zachęcie, 1908.

Fot. ze zbiorów Gab. Ryc. ASP w Krakowie

„idealne w gabinecie moralisty, kaznodziei, pedagoga, wprost bezlitosne są dla młodego małżeństwa"47. Odczuwano jednak, że projekty Wyspiańskiego mają wartość artystyczna, którą jest ,właściwie sama idea, czysta substancja poetyczna - abstrakcja najzupełniej odcięta od życia i jego praw współczesnych. Zarówno przeskromna prasłowiańska jadalnia, jak «kąt salonu», są raczej wizją marzeń, niż meblami»48.

Bardzo dobrze przyjętym przez krytykę wnętrzem okazała się jadalnia Dziewulskich projektu Wojtyczki. Komplet ten zbliżony był do wyposażenia sali restauracyjnej w Starym Teatrze. Meble wykonano z politurowanego mahoniu, a pokrycia krzeseł z niebie-

\footnotetext{
${ }^{47}$ NOWACZYŃSKI, op. cit.

${ }^{48}$ GAWIŃSKI, op. cit.
} 
skiej tkaniny ${ }^{49}$. Chociaż nie nawiązywały bezpośrednio do biedermeieru, sprzęty te przywodziły na myśl wnętrza z pierwszej połowy XIX w. ${ }^{50}$ Ściany do wysokości około 1,5 metra obite zostały kilimem koloru kremowego z motywami ludowymi „drzewek” i „wieńców” o barwie fioletowej oraz żółtej. O pomieszczeniu pisano, że jest w nim „wesoło, lotnie, lekko", że bije z niego ,jakaś świeżość i wdzięk zarówno w kształcie mebli, jak i we wzorze na kilimach" ${ }^{1}$. Niewiele możemy powiedzieć o stole, który zasłonięty był na wystawie białym obrusem i tak też został utrwalony na fotografii. Wyraźnie widoczne są natomiast zaprojektowane przez Wojtyczkę krzesła z drewnianym siedziskiem i oparciem, a także fotele z siedziskiem wyściełanym i poręczami. Zarówno fotele, krzesła jak i kredens łączyła ornamentyka mająca swoje źródła w zdobnictwie ludowym. W oparciach foteli i krzeseł znalazły się serduszka, motyle, rozetki i linie faliste, fartuszki oskrzynienia zakończone były, podobnie jak meble ludowe, falistymi liniami, a górne ramiaki i wsporniki pod poręczami foteli oraz zwieńczenie kredensu zdradzało inspiracje wycinankami ludowymi. Umiejętne wykorzystanie tych ostatnich docenił Jaroszyński, który orzekł jednak także, że „kredens, zbudowany w duchu nowomodnej modły razi niekonsekwencją wiszących w powietrzu szuflad"52 .

Czajkowski zaprezentował na wystawie fragment wyposażenia zaprojektowanego do przedpokoju w mieszkaniu Stefana Dziewulskiego. Meble te były wzorowane na podobnym komplecie z mieszkania prezydenta Krakowa Juliusza Leo. Na umeblowanie pomieszczenia składały się: lustro z konsolą, kanapa, fotele i stół; całości dopełniały portiery i kinkiety. Jak pisano, meble wykonane były z ,drzewa orzechowego, politurowanego, gdzieniegdzie złocone lub akcent ciemnogranatowy"53. Wszystkie sprzęty charakteryzowały się szlachetną prostotą i umiarkowaną monumentalnością. W ich formach dominowały linie proste, przełamane delikatnymi przecinającymi się łukami. O wnętrzu tym współcześni pisali, że sprawia wrażenie spokoju, powagi, ale też wygody ${ }^{54}$. Cechy te łączą meble Czajkowskiego z biedermeierem, którego wpływy szczególnie dobrze widoczne są w projekcie stolika i konsoli. Stolik wspiera się na środkowym filarze otoczonym ośmioma łukowatymi podporami. W konsoli jako podpory wykorzystano cztery kolumny, a w tylnej ściance mebla umieszczono lustro. Są to rozwiązania powszechnie stosowane w meblarstwie doby biedermeieru.

Nawiązania do sztuki 1. połowy XIX w. okazały się czytelne dla recenzentów wystawy. Jaroszyński pisał nawet, że projekt Czajkowskiego, prócz kilku indywidualnych urozmaiceń, przypomina meble z epoki Ludwika Filipa, ,jakie jeszcze do dziś spotykamy w starych dworach szlacheckich”. Następnie dodawał: „Ma to już dla nas urok pewnej swojskości, gdyż związane z tradycją dawnych generacji wywołuje szeregi wspomnień bardzo rodzimych" 55 . Czajkowski inspiracje biedermeierem połączył z motywami wywodzącymi się ze sztuki ludowej. Krytycy zwracali uwagę, że w rzeźbionych detalach mebli można odnaleźć ,daleki wzór zaczerpnięty z łyżników, a przepuszczony przez pryzmat wyobraźni artysty" "56. Zapewne uwaga ta wiązała się z motywem zygzaka umieszczonym

\footnotetext{
${ }^{49}$ Teki..., sygn. 20028, karta 12, 13: „Wystawa «polskiej sztuki stosowanej»”, op. cit.

50 Teki..., sygn. 20029, karta 197: KOTARBIŃSKA, op. cit.

${ }^{51}$ NOWACZYŃSKI, op. cit.; Teki..., sygn. 20028, karta 12, 13: „Wystawa «polskiej sztuki stosowanej»”, op. cit.

52 JAROSZYŃSKI, „Sztuka stosowana”, op. cit.; JAROSZYŃSKI, „Polska Sztuka Stosowana”, op. cit.

53 Teki..., sygn. 20028, karta 12, 13: „Wystawa «polskiej sztuki stosowanej»”, op. cit.

${ }^{54}$ Ibid.; Teki..., sygn. 20029, karta 197: KOTARBIŃSKA, op. cit.

55 JAROSZYŃSKI, „Polska Sztuka Stosowana”, op. cit.

${ }^{56}$ E. Żm. [Eugenia ŻMIJEWSKA], op. cit.
} 

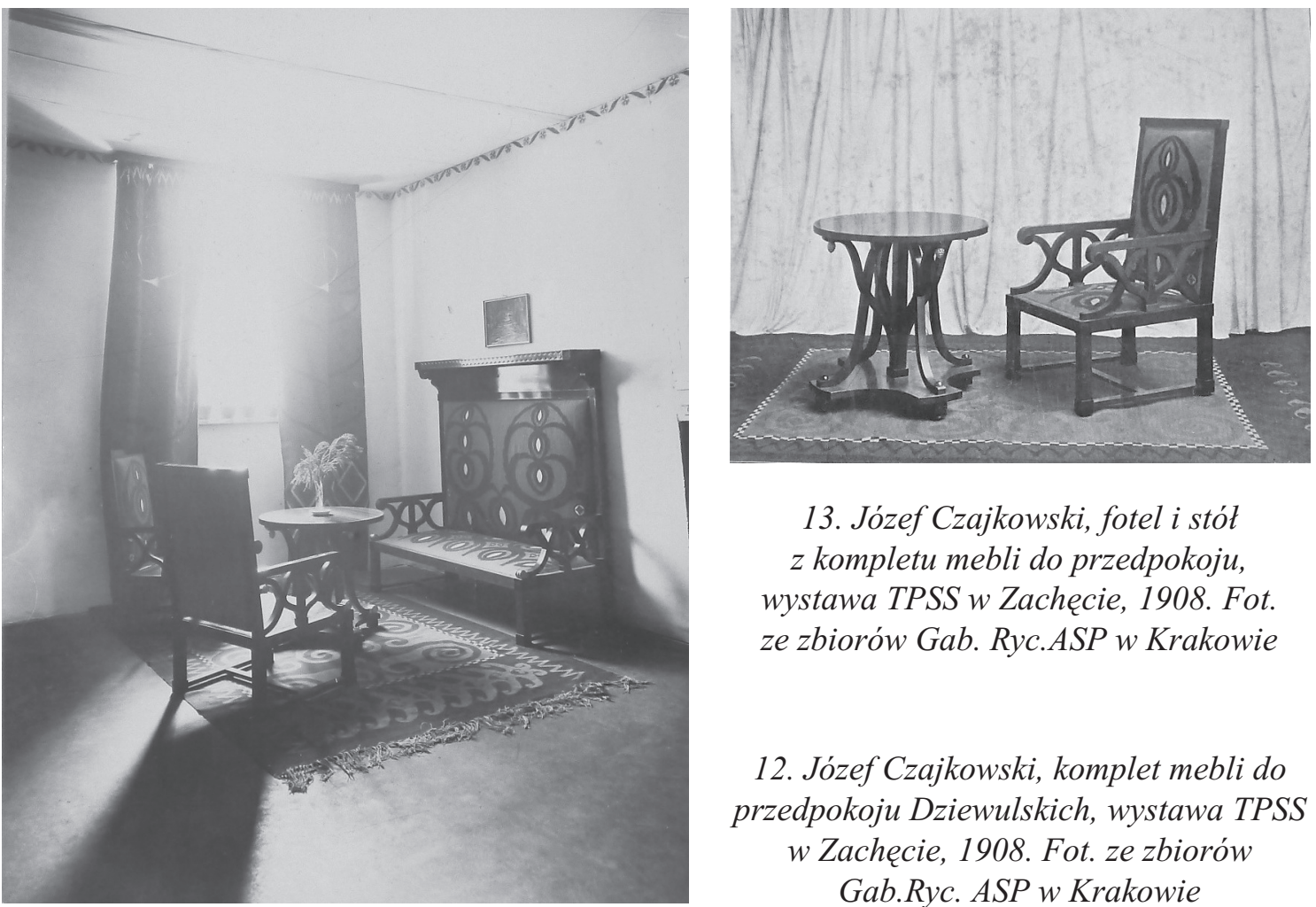

13. Józef Czajkowski, fotel i stót z kompletu mebli do przedpokoju, wystawa TPSS w Zachęcie, 1908. Fot. ze zbiorów Gab. Ryc.ASP w Krakowie

12. Józef Czajkowski, komplet mebli do przedpokoju Dziewulskich, wystawa TPSS w Zachęcie, 1908. Fot. ze zbiorów Gab.Ryc. ASP w Krakowie

w zwieńczeniu oparcia kanapy. Ludowe inspiracje widoczne są jednak przede wszystkim w projektach tkanin obiciowych na fotelach i kanapie, które wykonano z kilimów produkowanych w warsztacie Sikorskiej. Na portierach Czajkowski wykorzystał motyw pawiego pióra, na meblach zaś stworzył wzór z mocno przestylizowanych pawich oczek. Dzięki recenzjom dowiadujemy się jaką kolorystykę miały kilimy i portiery: „Kolor tkaniny szaro-zielony. Tego samego koloru portiery. Wzór ożywiony kolorem żółtym, białym i granatowym" 57 . Całości wystroju dopełniały rozłożony na podłodze kilim z motywem esownic i kinkiety lamp elektrycznych. Te ostatnie chwalono na łamach prasy za to, że: ,ich prosty, lapidarny rysunek doskonale nadaje się do wycięcia w metalu połyskliwym i żółtym, co bardzo dobrze harmonizuje z ornamentacją kilimów i ogólnym kolorem urządzenia"58.

Jednym z najlepiej ocenianych wnętrz była jadalnia Reymontów, również projektu Czajkowskiego. Pisano, że pokój ,śmieje się cały, zaprasza gości, rad, że w nim są, jest pogodny, wesoły, szczery, prosty"59. Twierdzono, że wnętrze to charakteryzuje „zrównoważenie architektoniczne, poczucie kształtów i logika w rozwiązaniu strony konstrukcyjnej" ${ }^{\prime 60}$. Do jadalni artysta zaprojektował kredens, dwie szafy na szkło i dwa typy krzeseł, a także stół oraz dwie szafki-pomocniki. Większość sprzętów, poza krzesłami, zachowała się w zbiorach Muzeum Literatury w Warszawie ${ }^{61}$. Meble wykonane zostały z jesionu, o którego kolorystyce pisano: „Żółty kolor politurowanego drzewa, gdzieniegdzie zaznaczony białym metalem lub ciemno granatowymi szczegółami w drzewie, [jest] dobrze

\footnotetext{
57 Teki..., sygn. 20028, karta 12, 13: „Wystawa «polskiej sztuki stosowanej»”, op. cit.

58 GAWIŃSKI, op. cit.

59 Teki..., sygn. 20029, karta 197: KOTARBIŃSKA, op. cit.

${ }^{60}$ Teki..., sygn. 20028, karta 12, 13: „Wystawa «polskiej sztuki stosowanej»”, op. cit.

${ }^{61}$ W Muzeum Literatury znajduje się także zestaw krzeseł i dwa lustra, które wtórnie zostały połączone z meblami projektu Czajkowskiego.
} 


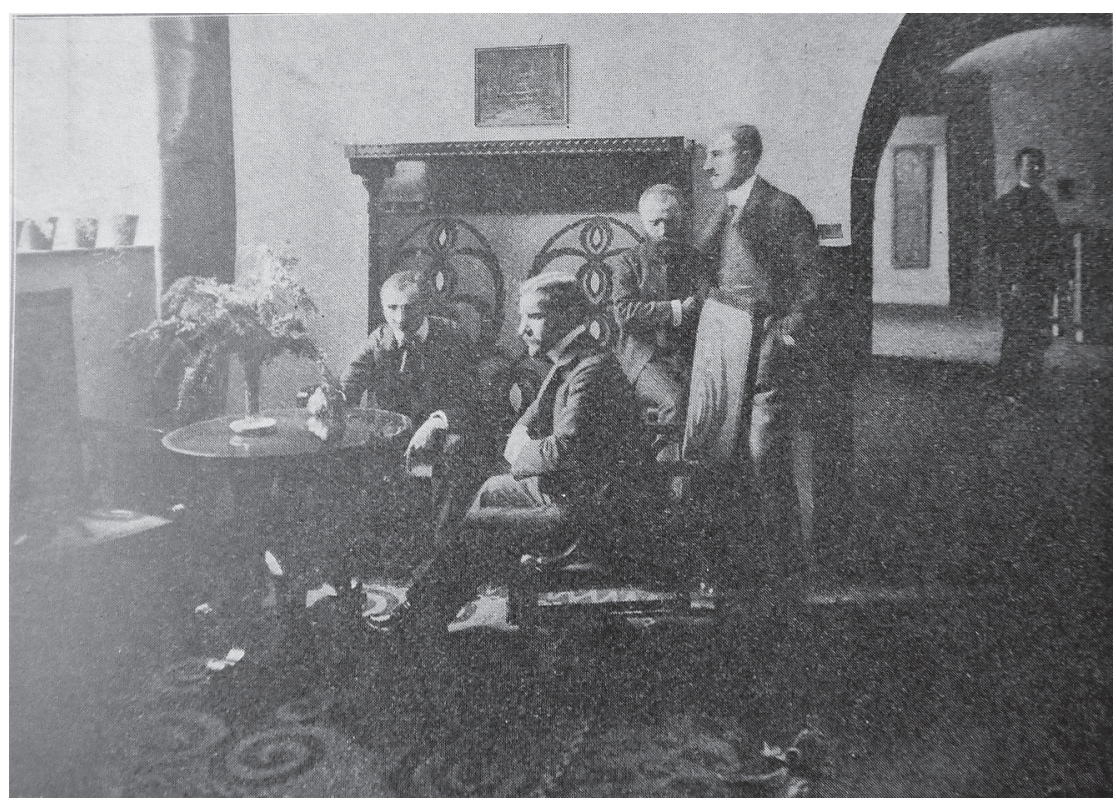

14. Od lewej Edward Trojanowski, Jerzy Warchałowski, Karol Tichy i Józef Czajkowski w przedpokoju projektu Józefa Czajkowskiego, wystawa TPSS w Zachęcie, 1908. Repr. wg „,Tygodnik Ilustrowany”, 1908, $n$ r 6, s. 119

zharmonizowany z zielonym kolorem ścian i pokrycia mebli" ${ }^{\prime 2}$. Komplet ten był wzorowany na meblach do sali restauracyjnej w Starym Teatrze.

We wszystkich sprzętach widoczne były cechy łączące je z meblarstwem epoki biedermeieru. Już współczesnym stworzone przez Czajkowskiego wnętrze przypominało meble z 1. połowy XIX w. i kojarzyło się z atmosferą dworku ${ }^{63}$. Ze stylem tym łączy komplet Czajkowskiego wiele elementów, m.in. wykorzystanie zarówno w kredensie, jak też szafkach i serwantkach filarków, które politurowane były na kolor granatowy. Nawiązaniem do epoki biedermeieru zdawały się być także przecinające się szprosy w przeszkleniach drzwi szafek oraz kształt krzeseł, który nawiązywał do północnoniemieckich siedzisk z początku XIX w. typu hamburka. Artysta wykorzystał też, tak jak czyniono to w epoce biedermeieru, walory dekoracyjne usłojenia drewna, co widoczne jest zwłaszcza na drzwiach kredensu i szafek. Czajkowski te ewidentnie biedermeierowskie cechy subtelnie połączył z elementami mającymi swoje źródło w sztuce ludowej. W dekoracjach oparć krzeseł i w podpórkach poręczy skorzystał z form zaczerpniętych z wycinanek, a w kredensie i serwantkach zastosował oskrzynienia nawiązujące do elementów z meblarstwa ludowego. Z ludowym sprzętarstwem wiąże się też gzyms kredensu, zakończony od dołu deseczką z naprzemiennymi ząbkami i linią falistą, a także gwiazdki na drzwiach kredensu i szyldziki.

Kilimy powstałe w warsztatach czernichowskich dekorowały prawie wszystkie pokoje. Rozłożono je na podłogach, kanapach i stołach. Służyły jako tkaniny obiciowe, pokrywały ściany zastępując boazerie czy lamperie, stały się też portierami. Kilimy autorstwa Warchałowskiego, Trojanowskiego, Tichego i Kazimierza Brzozowskiego pojawiły się

\footnotetext{
${ }^{62}$ Teki..., sygn. 20028, karta 12, 13: „Wystawa «polskiej sztuki stosowanej»”, op. cit.

${ }^{63}$ BRONIEWSKI, op. cit.; Teki..., sygn. 20029, karta 197: KOTARBIŃSKA, op. cit.; GAWIŃSKI, op. cit.; Teki..., sygn. 20028, karta 12, 13: „Wystawa «polskiej sztuki stosowanej»”, op. cit.
} 


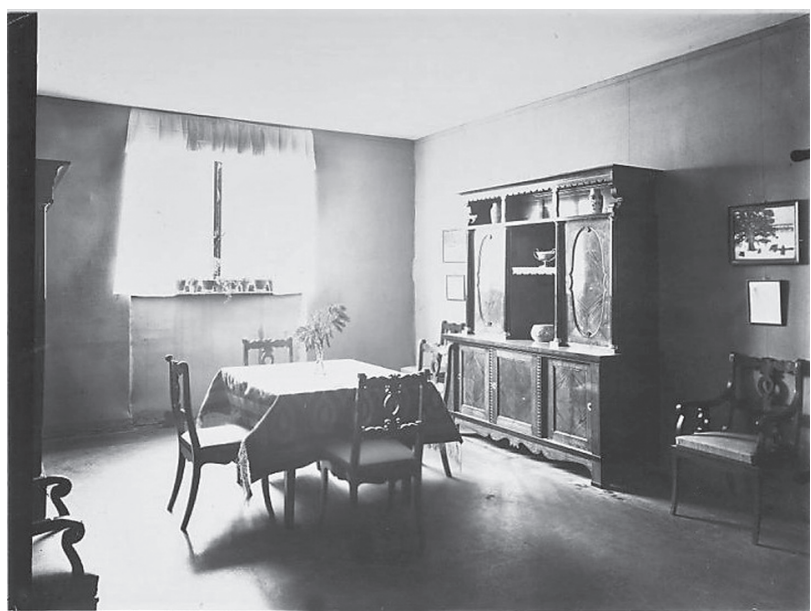

15-16. Józef Czajkowski, komplet mebli do jadalni Wtadystawa Reymonta i fotel z tego kompletu, wystawa TPSS w Zachęcie, 1908.

Fot. ze zbiorów Gab. Ryc.ASP w Krakowie

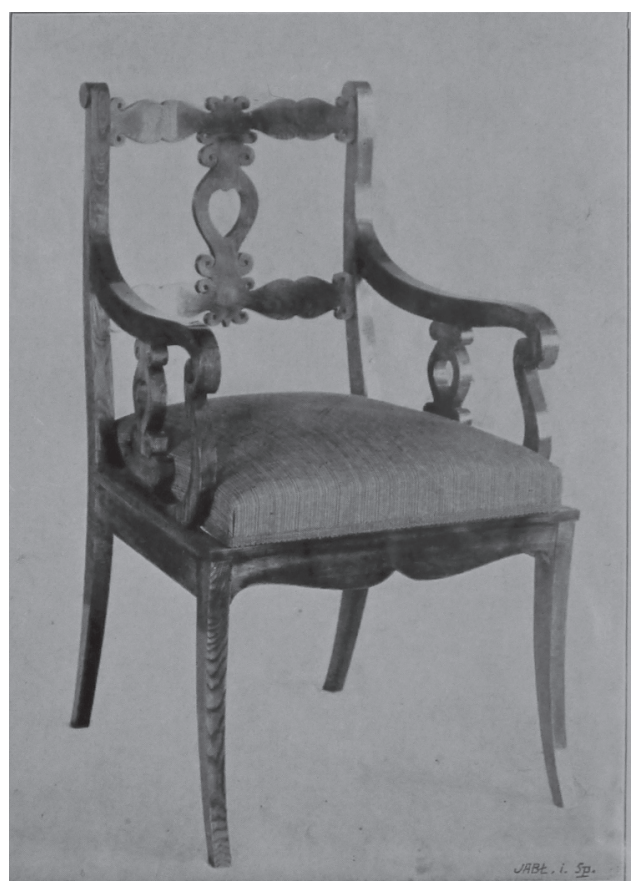

także w innych częściach wystawy, poza zaaranżowanymi wnętrzami. Podziwiano w nich różnorodność motywów, których punktem wyjścia były inspiracje sztuką ludową (m.in. motywami wycinanek) ${ }^{64}$. Niektórzy widzowie sądzili jednak, że kilimy są „nieco monotonne i ściśle ograniczające się do działania tylko barwą skutkiem czego szybko opatrzone i wprost nużące" ${ }^{65}$. Inni tymczasem pisali, że ,wielkie plamy wzorzystości [ich] drażnią jak afisz krzykliwy”"66. Stifelman notował zaś, że „,wełniaków” nie można używać jako portier lub obić ścian ponieważ ,je mole wkrótce doszczętnie zniszczą" ${ }^{967}$.

Powszechnie chwalono salę zapełnioną pracami Mehoffera; pojawiały się nawet głosy, że jest to najciekawsza część wystawy ${ }^{68}$. Pokazano w niej między innymi witraże z zakładu Żeleńskiego (Vita somnium breve, Caritas), kartony do kaplic Świętokrzyskiej i Szafrańców na Wawelu, skarbca wawelskiego, kaplicy w Gołuchowie, projekty wnętrza i polichromii Izby Przemysłowo-Handlowej w Krakowie, a także fragmenty dekoracji sali wystawowej w Monachium z roku $1905^{69}$.

Krytycy zwracali również uwagę na projekty polichromii wnętrz kościelnych. Pozytywnie wzmiankowano prace autorstwa Jana Bukowskiego do kościoła w Stryszowie, Franciszka Bruzdowicza w Cimkowiczach, Karola Maszkowskiego w Pilźnie i Henryka Uziembły w Sosnowcu ${ }^{70}$. Pokazano również dzieła powstałe w krakowskich zakładach

\footnotetext{
${ }^{64}$ E. Żm. [Eugenia ŻMIJEWSKA], op. cit.

${ }^{65}$ NOWACZYŃSKI, op. cit.

${ }^{66}$ BRONIEWSKI, op. cit.

${ }^{67}$ STIFELMAN, op. cit.

${ }^{68}$ NOWACZYŃSKI, op. cit.; GAWIŃSKI, op. cit.; Teki..., sygn. 20029, karta 198, 199: Stefan POPOWSKI, „Sztuka stosowana”, Gazeta Codzienna, 1908, [niezidentyfikowany numer]; BRONIEWSKI, op. cit.; Teki..., sygn. 20028, karta 12, 13: „Wystawa «polskiej sztuki stosowanej»”, op. cit.; Stefan POPOWSKI, „Wystawa Krakowskiego Towarzystwa «Polska Sztuka Stosowana»", Sfinks, 1908, t. 1, nr 1-3, s. 343-347.

${ }^{69}$ Wystawa krakowskiego Towarzystwa „Polska Sztuka Stosowana” w gmachu Towarzystwa Zachęty Sztuk Pięknych w Warszawie w lutym 1908 r., op. cit., s. 10-12.

${ }^{70}$ NOWACZYŃSKI, op. cit.; POPOWSKI, „Wystawa Krakowskiego Towarzystwa «Polska Sztuka Stosowana»”, op. cit.; Teki..., sygn. 20028, karta 12, 13: „Wystawa «polskiej sztuki stosowanej»”, op. cit.; „Wystawa Sztuki Stosowanej”, Architekt, 1908, nr 2-3, szp. 28-31.
} 


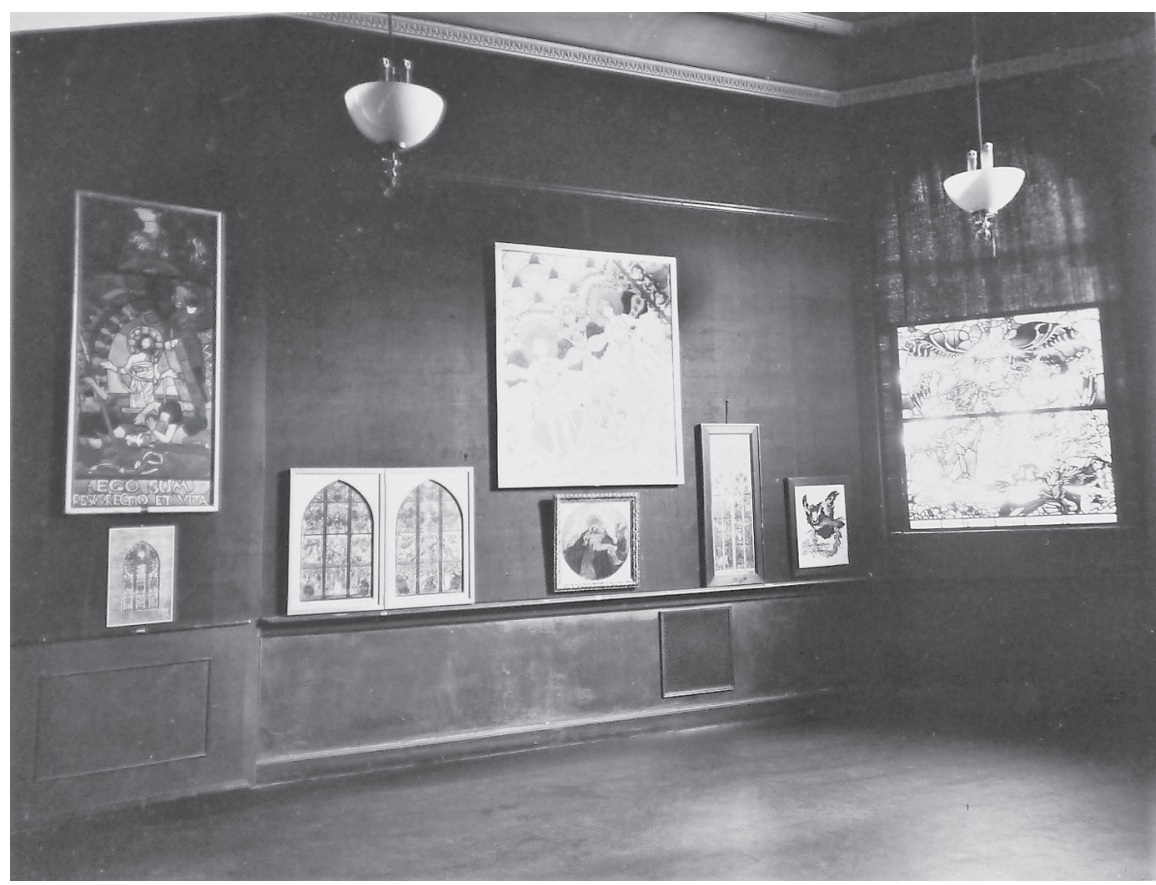

17. Sala z pracami Józefa Mehoffera, wystawa TPSS w Zachęcie, 1908. Fot. ze zbiorów Gab. Ryc.ASP w Krakowie

współpracujących z TPSS - witraże z pracowni Żeleńskiego projektu Anny GramatykiOstrowskiej i Franciszka Mączyńskiego oraz majoliki z fabryki Niedźwieckiego autorstwa Jana Szczepkowskiego ${ }^{71}$. Towarzyszyły im afisze Brzozowskiego, Mehoffera, Antoniego Procajłowicza, Trojanowskiego, Uziembły i Wojtyczki. Niestety, katalog wystawy z 1908 r. nie precyzuje, jakie afisze zaprezentowano. Większość $\mathrm{z}$ nich została wykonana $\mathrm{w}$ technice litografii w Zakładzie Aureliusza Pruszyńskiego ${ }^{72}$.

W jednej sali zaprezentowano druki - okładki, ilustracje, książki, kalendarze, druki akcydensowe i muzyczne. Wystawiono projekty Bukowskiego, Czajkowskiego, Eugeniusza Dąbrowy-Dąbrowskiego, Stanisława Dębickiego, Karola Frycza, Gramatyki-Ostrowskiej, Stanisława Kamockiego, Mehoffera, Fryderyka Pautscha, Procajłowicza, Franciszka Siedleckiego, Trojanowskiego, Tadeusza Rychtera, Wojciecha Weissa, Uziembły, Leona Wyczółkowskiego i Wyspiańskiego. W katalogu nie podano, jakie druki eksponowano, wymieniono jedynie wydawców i drukarnie. Jak zwykle TPSS szczyciło się wydawnictwami własnymi. Jednak można było zauważyć też liczne wydawnictwa warszawskie m.in. „Chimerę” oraz druki oficyn Jakuba Mortkowicza, Stefana Dembego, oficyny Gebethner i Wolff i innych ${ }^{73}$.

Informacje prasowe na temat druków były raczej pozytywne, a czasami wręcz entuzjastyczne. Stefan Popowski pisał: „Przywrócono godność książce. Królewnie, którą spekulacja księgarska ubierała w trywialne szaty kokoty, albo łachmany kopciuszka, przywrócono z powrotem należny jej strój królewski" ${ }^{74}$. Wystawę w warszawskiej Zachęcie uznano za

\footnotetext{
71 Wystawa krakowskiego Towarzystwa „Polska Sztuka Stosowana” w gmachu Towarzystwa Zachęty Sztuk Pięknych w Warszawie w lutym 1908 r., op. cit., s. 13, 15, 16.

72 Ibid.

${ }^{73}$ Ibid., s. 18, 19.

${ }^{74}$ Teki..., sygn. 20029, karta 198, 199: POPOWSKI, „Sztuka stosowana”, op. cit.
} 
triumf krakowskich twórców z dziedziny projektowania graficznego. Zauważana i komentowana była diametralna różnica między poziomem druków krakowskich i warszawskich. Według Trojanowskiego w Warszawie dominować miały wydawnictwa, wewnątrz których zobaczyć można było ,zbite nieczytelne czcionki, złe ustawienie kolumny, papier przezroczysty, nietrwały, a zewnatrz groch z kapustą - tytuł wydrukowany czterema garniturami czcionek”. Co więcej, jego zdaniem nie czyniono ,absolutnie żadnych a żadnych usiłowań w kierunku zmiany obecnych warunków"75.

Mimo że na wystawę mogli zgłaszać prace także artyści niezwiązani z TPSS, w katalogu wystawy nie odnajdujemy zbyt wielu twórców spoza środowiska krakowskiego. Pojawiły się, oprócz druków pochodzących z warszawskich wydawnictw, jedynie drzeworyty Piotra Krasnodębskiego, ilustracje Janusza Nawroczyńskiego, projekty wnętrz zamku wawelskiego autorstwa Stanisława Noakowskiego i model kościoła Zygmunta Otto. TPSS doceniło również fotografie powstałe w Warszawskiej Szkole Fotograficznej pod kierunkiem Włodzimierza Kirchnera ${ }^{76}$.

Celem wystawy było wykazanie, że polska sztuka stosowana już istnieje, a szereg artystów działa na tym polu. Sądzę, że TPSS udało się osiągnąć ten cel. W „Architekcie” z entuzjazmem pisano: „Sztuka stosowana polska - jest!”77. Jan Kleczyński na łamach „Tygodnika Ilustrowanego” oznajmiał zaś: „Odnieśliśmy wielkie zwycięstwo [...] To nowy Grunwald! To ma takie znaczenie, jak wielkie zwycięstwa polityczne. To uszlachetni całe nasze życie"78. Wystawa udowodniła, że sztuka stosowana nie jest bynajmniej rodzajem twórczości „niższego rzędu” czy pośledniego gatunku. „Trzeba raczej uznać fakt zgoła przeciwnego znaczenia: że prosty stołek, nóż, czy okładka do książki, mająca swój styl, jest sztuką znacznie «wyższą», istotniejszą, niż «najprawdziwszy» krajobraz bez stylu, bez oryginalnego ujęcia, bez duszy"79 - dowodził Kleczyński.

Twórcom udało się uzyskać we wnętrzach efekt harmonii. W prasie odnotowano, że „Artyści nie ograniczają się do tworzenia luźnych sprzętów i ornamentyki, lecz szukają architektonicznego porządku w całokształcie pokojowego wnętrza i logiki w planie mieszkania" ${ }^{80}$. Osiagnnięto ten cel „zestrojem kolorystycznym mebli, ścian, sufitów”, któremu partnerował ,architektoniczny porządek, wyrażony w podziale ścian, ustawieniu mebli, zawieszeniu obrazów” oraz „brak przeładowania drobiazgami i zbyteczną ornamentacją" "81. Zwracano także uwagę, że TPSS proponuje nowoczesne, higieniczne rozwiązania w projektowaniu wnętrz, postulując budowanie niezbyt wysokich, ale dobrze oświetlonych pomieszczeń. Tę tendencję z uwagą obserwowali krytycy, którzy zauważali, że nowocześnie i zarazem harmonijnie urządzony dom ,urasta na wystawie do znaczenia dzieła sztuki w każdym sprzęcie, w każdym drobiazgu"82.

W projektach wnętrz zaprezentowanych na wystawie można było wskazać zarówno inspiracje meblarstwem biedermeieru, jak i nawiązania do sztuki ludowej. Krytycy zwie-

\footnotetext{
75 Edward TROJANOWSKI, „Słów kilka o drukarstwie z powodu wystawy Krakowskiego Towarzystwa Polska Sztuka Stosowana", Przewodnik Biblioteczny, 1908, z. 2, s. 117-120.

76 Wystawa krakowskiego Towarzystwa „Polska Sztuka Stosowana” w gmachu Towarzystwa Zachęty Sztuk Pięknych w Warszawie w lutym 1908 r., op. cit., s. 13, 15, 17, 19.

77 „Wystawa Sztuki Stosowanej”, Architekt, op. cit.

78 Jan KLECZYŃSKI, „Znaczenie Wystawy Polskiej Sztuki Stosowanej w Warszawie”, Tygodnik Ilustrowany 1908, nr 5, s. 101, 102.

${ }^{79} \mathrm{Ibid}$.

80 „Wystawa Sztuki Stosowanej”, Architekt, op. cit.

${ }^{81}$ Teki..., sygn. 20028, karta 12, 13: „Wystawa «polskiej sztuki stosowanej»”, op. cit.

82 Teki..., sygn. 20029, karta 197: KOTARBIŃSKA, op. cit.
} 
dzający wystawę odnosili wrażenie, że artyści kręgu TPSS wytworzyli odrębny styl mający rzucać się w oczy „,swojszczyzną, którą się odgaduje, wyczuwa nieraz z kilku linii charakterystycznych, nieraz z małego zdobniczego szczegółu, rzeźbionego fryzu, kilku barw zestawionych" 83 . Broniewski zwracał uwagę, że odczuwalny jest w projektach TPSS pewien rys archaizujący oraz dominacja kształtów ciężkich i poważnych ${ }^{84}$. Komentatorzy poszukiwali źródeł tego stylu. Jaroszyński dopatrywał się wpływu secesji zachodnioeuropejskiej ${ }^{85}$. Podobnie uważał Stiefelman, który dowodził, że prezentowane meble „w całości noszą piętno obce, modernistyczne" 86 . Podkreślano jednak także subtelne nawiązania do polskiej sztuki dawnej ${ }^{87}$. „Tam było [...] coś z siebie i coś z tradycji... Z tych miłych czasów, kiedy babki nasze - podówczas młode i piękne - siedząc za szpinetem - śpiewały dorodnym ułanom niezapomnianą pieśń o Filonie..." - pisał Niewiadomski ${ }^{88}$. Krytyczny w swych sądach Stifelman dowodził tymczasem, że odwoływanie się do meblarstwa epoki empiru i biedermeieru nie może być wyrazem ,swojskości” i ,równie swojskim będzie musiał się wydawać naszym prawnukom dobry mebel modernistyczny". Pisał również, że nawiązania do „staroświecczyzny” są nieracjonalne, ponieważ już nie odpowiadają współczesnym potrzebom ekonomicznym, estetycznym i higienicznym ${ }^{89}$.

Wystawa warszawska udowodniła krytyce i publiczności, że realizacje artystów związanych z TPSS nie są jedynie biernym, bezrefleksyjnym kopiowaniem motywów ludowych, jak twierdzili niektórzy krytycy. Nowaczyński pisał: „Całość wystawy przekonywa, że Sztuka stosowana wyszła już z fazy «kogutkowej» z forsownego przełamywania swych wytworów elementami ludowymi, branymi ze skrzyń, fartuchów, łyżników wprost i nad miarę. Również maniactwo zakopiańskiego stylu nieco ochłodło. Obecnie motywy brane z obfitych materiałów zdobniczej sztuki ludowej ulegają szczęśliwej selekcji, całkowitym przetrawieniom i transformacjom" 90 . Zwracano uwagę, że sztuka ludowa rozbudziła wyobraźnię artystów i skłoniła do tworzenia w sposób oryginalny ${ }^{91}$. Znaleźli się jednak krytycy, którzy uważali, że artyści zbyt biernie kopiują ludowe motywy. Tego zdania był Stifelman, który w „Przeglądzie Technicznym” pisał, że ornamentyka „często bez związku z ozdabianym dziełem [...] mogłaby służyć z równym powodzeniem i do innej książki. Niewłaściwość ta musi rychło sprowadzić [...] do niepożądanego wyjałowienia, do łatwego naśladownictwa - do tuzinkowej fabrykacji"92.

Meble i wnętrza zaprezentowane w Zachęcie spotkały się z zarzutem, że są przeznaczone jedynie dla zamożnych klientów. Popowski notował: ,[...] sprzęty ładne jako pomysły konstrukcyjne, są wytworne zestawienia barw, zgrabnie rysowane desenie, lecz tego nie dość... A gdzie tam na wystawie «człowiek średnio-zamożny»" 93 . Ten sam autor twierdził, że sprzęty są zbyt „kosztowne, zbytkowne” dla ludzi średniozamożnych ${ }^{94}$. W obronie artystów występował Jan Kleczyński, który wyraził przekonanie, że projektant

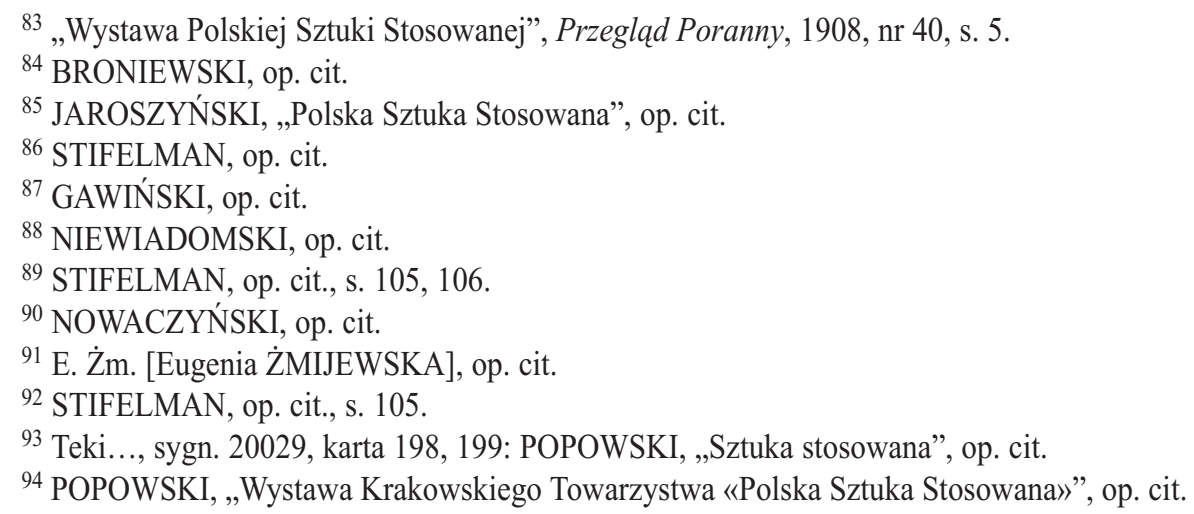


„uwzględnia jedynie to, by użyto odpowiedniego materiału do jego dzieła, a nic go nie obchodzi cena tego materiału! Demokratyzacja, popularyzowanie tworu artysty do niego już nie należy. To rzecz społeczeństwa...”. Dlatego też postulował zakładanie fabryk, które będą produkować tanie sprzęty w stylu swojskim ${ }^{95}$.

Niektóre wnętrza, a zwłaszcza meble artystów TPSS, spotykały się z zarzutem, że są całkowicie niepraktyczne. Szczególnie pozbawione cech utylitarnych miały być meble Wyspiańskiego i Trojanowskiego. Broniewski dowodził, że w przypadkach obu artystów „praktyczne przeznaczenie wykonanego sprzętu ustąpiło całkowicie miejsca i racji swojej jakiejś chęci wywołania nastroju mistycznego wagą i rozmiarami przedmiotów [...] są one ustawione raz na zawsze, umontowane niby jakieś machiny, których poruszać się nie powinno, że człowiek do nich, nie one do niego, winien się przystosować". Broniewski zwracał także uwagę, że najważniejsze w projektowaniu jest ,przeznaczenie i dogodność w użyciu" "96. Jaroszyński tymczasem przypominał, że „Rzecz jest piękna, jeśli doskonale odpowiada swojemu celowi” i sugerował artystom, że powinni nawiązać współpracę z inżynierami ${ }^{97}$. Zarzucał twórcom mebli niekonsekwencję „,w przeprowadzeniu pomysłów zdobniczych w stosunku do wymagań konstrukcyjnych", a także stosowanie niezgodnych z formą materiałów. Według Jaroszyńskiego TPSS, zamiast zainspirować się w pełni ,sprzętarstwem ludowym”, skorzystało jedynie z jego form, stosując jednak nadal cenne gatunki drewna. „Ciężkie i sztywne formy sprzętarstwa ludowego, czy też w ogóle hieratycznego, wykonać kazano najpierwszorzędniejszym stolarzom z drogiego i pięknie politurowanego drewna" - notował z dezaprobatą ${ }^{98}$.

Wystawa TPSS wywołała serię postulatów na przyszłość. Wskazywano oczywiście na potrzebę założenia warsztatów doświadczalnych ${ }^{99}$, a także na zasadność nawiązania współpracy pomiędzy architektami a projektantami wnętrz ${ }^{100}$. Ekspozycja rozbudziła nadzieje na powołanie do życia fabryki produkującej meble w stylu swojskim ${ }^{101}$. Nowaczyński snuł plany, że centrum rozwoju sztuki stosowanej powinno przenieść się z Galicji do Królestwa, które posiadało znacznie większe zasoby finansowe. Sądził, że reorganizacja szkoły sztuki dekoracyjnej w Warszawie przyczyniłaby się do rozwoju tej gałęzi sztu$\mathrm{ki}^{102}$.

\footnotetext{
95 Jan KLECZYŃSKI, „Demokratyzacja «Sztuki Stosowanej»”, Tygodnik Ilustrowany, 1908, nr 15, s. 300, 301.

${ }^{96}$ BRONIEWSKI, op. cit.

97 JAROSZYŃSKI, „Sztuka stosowana”, op. cit., s. 5.

98 JAROSZYŃSKI, „Polska Sztuka Stosowana”, op. cit.

99 Teki..., sygn. 20029, karta 197, 198: Leon CHOROMAŃSKI, „Wystawa Sztuki Stosowanej”, Społeczeństwo, 1908, nr 7 (14 II), s. 104-105.

100 „Wystawa Sztuki Stosowanej”, Architekt, op. cit.

101 Jan KLECZYŃSKI, „Wystawa Polskiej Sztuki Stosowanej w Warszawie”, Tygodnik Ilustrowany, 1908, nr 6, s. 118, 119.

102 NOWACZYŃSKI, op. cit.
} 


\section{'Warsaw Has Never Seen Anything Like It'. Exhibition of the Society of Polish Applied Art at the Zacheta in 1908}

In February and March 1908, the Zachęta Society for the Encouragement of Fine Arts in Warsaw presented a summing-up display of the activity of the Kraków Society of Polish Applied Art (TPSS), active from 1901. According to some comments: 'The goal of the Exhibition was to demonstrate that Polish applied art existed, that there were already a number of artists who for the last several years had been aware of their purpose, thus demonstrating that when it came to decorating dwelling interiors, particularly when cabinetmaking and wall decorating were concerned (...), they were able to take an independent and thoroughly artistic stand in the full meaning of the term'. The display filled in ten rooms, seven of them being dwelling interior arrangements. The presented designs included those by: Karol Tichy (entryway), Edward Trojanowski (Władysław Reymont's study, Papal bedroom), Stanisław Wyspiański (the Żeleńskis' dining- and drawing-rooms), Ludwik Wojtyczko (the Dziewulskis' dining-room), and Józef Czajkowski (hall in the flat of Kraków's Mayor; the Reymonts' dining-room). Arranging Zachęta's spaces as a line of dwelling interiors aroused much interest of the critics, while Eligiusz Niewiadomski wrote: 'Warsaw has never seen anything like it'.

The Exhibition proved that TPSS had reached its goals: it inspired interest in applied art: moreover, it encouraged painters and architects to undertake attempts to design interiors, furniture, and textiles, thus also raising the status of decorative art, and displaying models of coherently designed interiors that had already reached the status of art. In the eyes of reviewers, the shown furniture and arrangements featured a distinguishable style characteristic of TPSS, which no longer was a passive copying of folk-art-derived models (something TPSS had been criticized for earlier). Despite numerous successes, the Society had to face some reviewers' criticism; it was claimed that the designers did not fully take into account utilitarian aspects; according to those critical views, neither did they bear in mind the potential costs of mass production.

Translated by Magdalena Iwińska 
